FIU Law Review

Fall 2014

Interpreting the Definition of a Whistleblower under Dodd-Frank's Anti-Retaliation Provision: How andWhy Public Policy Should Guide the Courts in Finding that Whistleblowers Do Not Need to Report to the SEC

Stephanie Klein

Florida International University College of Law

Follow this and additional works at: https://ecollections.law.fiu.edu/lawreview

Part of the Other Law Commons

Online ISSN: 2643-7759

Recommended Citation

Stephanie Klein, Interpreting the Definition of a Whistleblower under Dodd-Frank's Anti-Retaliation Provision: How andWhy Public Policy Should Guide the Courts in Finding that Whistleblowers Do Not Need to Report to the SEC, 10 FIU L. Rev. 279 (2014).

DOI: https://dx.doi.org/10.25148/lawrev.10.1.15

This Comment is brought to you for free and open access by eCollections. It has been accepted for inclusion in FIU Law Review by an authorized editor of eCollections. For more information, please contact lisdavis@fiu.edu. 


\title{
Interpreting the Definition of a Whistleblower under Dodd-Frank's Anti-Retaliation Provision: How and Why Public Policy Should Guide the Courts in Finding that Whistleblowers Do Not Need to Report to the SEC
}

\author{
Stephanie Klein ${ }^{*}$
}

\section{INTRODUCTION}

Broadly, this Comment addresses the question of whether the term "whistleblower," as used in the Dodd-Frank Act ("Dodd-Frank"), requires a person to report concerns to the Securities and Exchange Commission ("SEC") to later bring a retaliation action. More specifically, this note focuses on the tension between two specific sections of the whistleblower provisions under Dodd-Frank, the definition of a whistleblower under title 15 U.S.C. $\S 78 \mathrm{u}-6(\mathrm{a})(6)$, and the anti-retaliation provision under title 15 U.S.C. $\S 76 \mathrm{u}-6(\mathrm{~h})(1)(\mathrm{A})(\mathrm{iii})$. The more specific question in the context of the latter provision is whether a whistleblower, who reports disclosures required under the Sarbanes Oxley Act of 2002 ("SOX"), must report that information to the SEC to be eligible to bring a retaliation claim under Dodd-Frank.

This issue has arisen in the United States district courts, which have generally interpreted the whistleblower provisions broadly to allow a whistleblower who reports a violation of SOX to bring a retaliation claim under Dodd-Frank without first reporting that claim to the SEC. In July 2013 however, the Fifth Circuit was the first federal circuit court to rule on this issue, and ruled in opposition to the trend in the district courts, construing the whistleblower provisions narrowly, thereby requiring a whistleblower who reports a violation of SOX to report to the SEC in order to bring a retaliation claim under Dodd-Frank. As more of these district court decisions are appealed to the circuit courts, there will likely be a circuit split on the issue, making the issue one that should eventually rise to the level of the Supreme Court.

Part I of this Comment provides an overview of the relative statutory provisions. First, SOX is analyzed by reviewing its anti-retaliation provisions and the Congressional intent upon its creation after the Enron scandal. The perceived failures of SOX are also addressed. Although the issue described above concerns specific provisions under Dodd-Frank, SOX is an important predecessor to Dodd-Frank and the interplay between the two statutes' whistleblower provisions is given consideration in the courts' analyses in order to interpret the whistleblower provisions under DoddFrank. Second, Dodd-Frank is analyzed by reviewing its anti-retaliation

J.D. Candidate, Florida International University College of Law, May 2015.

1 See infra Part II. 
[Vol. 10:279

provisions and the Congressional intent upon its creation after the 2008 economic recession. Finally, the conflicts and questions raised by DoddFrank's enactment after SOX, and Dodd-Frank's amendments to SOX's whistleblower provisions are addressed.

Part II of this Comment discusses the case law on this issue. First, the only federal circuit court case to hear the issue, Asadi v. GE Energy, is described in detail. Second, the district court cases on the issue are reviewed by: (i) describing in detail the three pre-Asadi district court cases that held in opposition to Asadi; (ii) briefly reviewing the post-Asadi district court cases that disagree with Asadi's holding; and (iii) briefly reviewing the post-Asadi district court cases that agree with Asadi's holding.

Part III engages in an analysis of how the term whistleblower should be construed. More specifically, this Part argues that a whistleblower who reports disclosures required by SOX should be able to file a retaliation claim under Dodd-Frank without reporting directly to the SEC. This conclusion is reached on two bases. First, an analysis of traditional canons of statutory interpretation lends support to this conclusion. Second, public policy, although a non-traditional mode of statutory interpretation, leads to this result and is perhaps the best means of resolving this conflict.

Overall, this Comment rejects the Asadi Court's holding and suggests that the Dodd-Frank anti-retaliation provision should be broadly construed in accordance with the majority of the district courts' reasoning, in order to allow a whistleblower who reports violations of SOX to bring a retaliation claim under Dodd-Frank without first reporting to the SEC.

\section{PART I}

\section{Relevant Statutory Provisions}

\section{A. The Sarbanes- Oxley Act of 2002}

The Sarbanes-Oxley Act of 2002 ("SOX") was enacted in response to a range of public accounting scandals that occurred between 2000 and 2002 in hopes of addressing and preventing the causes of the ensuing crisis. ${ }^{2}$ The most well-known of these scandals involved the Enron Corporation. At the time, Enron was believed to be one of the most financially sound companies in the U.S., and the collapse of Enron alerted the country to the need for

2 See Richard Moberly, Sarbanes-Oxley's Whistleblower Provisions: Ten Years Later, 64 S.C. L. Rev. 1, 3 (2012); see also Jennifer Christian, Whistleblower Protection Under Sarbanes-Oxley: Key Provisions and Recent Case Developments, 31 OKLA. CiTY U. L. REV. 331, 332 (2006) (before SOX's whistleblower provisions were created, federal statutes existed which provided whistleblower protections but only to those employees of specific government organizations for violations of specific federal laws). 
drastically different public accounting and auditing standards. ${ }^{3}$ The Enron scandal, which was revealed in late 2001, has been briefly described as follows:

In just 15 years, Enron grew from nowhere to be America's seventh largest company, employing 21,000 staff in more than 40 countries. But the firm's success turned out to have involved an elaborate scam. Enron lied about its profits and stands accused of a range of shady dealings, including concealing debts so they didn't show up in the company's accounts. As the depth of the deception unfolded, investors and creditors retreated, forcing the firm into Chapter 11 bankruptcy. ${ }^{4}$

Sarbanes-Oxley aimed to "reduce fraud by forcing corporations to submit more reliable financial statements and to ensure that auditors could recognize problems at earlier points in time.... SOX was supposed to minimize fraud perpetrated by individuals within the corporation or closely connected to it." SOX was also created in an attempt to calm the panic that surrounded the economic crisis caused by such scandals. ${ }^{6}$

In response to the crisis and in preparation of enacting the legislation, congressional hearings were held in developing and cultivating SOX's provisions. In particular, one Enron whistleblower's story sparked an outcry in Congress. ${ }^{7}$ This whistleblower attempted to oust Enron's

3 See Rosemary Peavler, The Sarbanes-Oxley Act and the Enron Scandal-Why are they Important?, ABOUT MONEY, http://bizfinance.about.com/od/smallbusinessfinancefaqs/a/sarbanes-oxleyact-and-enron-scandal.htm (last visited Feb. 11, 2014).

4 Enron Scandal at-a-Glance, BBC NEws (Aug. 22, 2002), http://news.bbc.co.uk/2/hi/business/ 1780075.stm.

5 Umang Desai, Crying Foul: Whistleblower Provisions of the Dodd-Frank Act of 2010, 43 LoY. U. CHI. L.J. 427, 442 (2012).

6 See A price worth paying?, THE ECONOMIST (May 19, 2005), http://www.economist.com/node/ 3984019; Simon Romero \& Riva D. Atlas, Worldcom's Collapse: The Overview; Worldcom Files for Bankruptcy; Largest U.S. Case, THE NY TIMES, (July 22, 2002), http://www.nytimes.com/2002/07/22/ us/worldcom-s-collapse-the-overview-worldcom-files-for-bankruptcy-largest-us-case.html (during the same timeframe, Worldcom was also involved in an accounting scandal, which involved the company's creation of billions of dollars in false earnings, that contributed to the crisis in 2002, and eventually submitted the largest bankruptcy filing in U.S. history.).

7 See Moberly, supra note 2, at 5 ("During the Congressional hearings preceding SarbanesOxley's enactment, an internal accountant from Enron named Sherron Watkins gave crucial testimony detailing the way in which the company manipulated its finances to create the illusion of value. She also testified that she informed CEO Ken Lay about the widespread financial improprieties, first through an anonymous letter and then in a personal meeting. When Andrew Fastow, Watkins's supervisor, found out about the meeting, Fastow tried to fire her. Moreover, the human resources department asked its outside counsel for advice on whether Watkins could be fired after reporting accounting fraud. The advice from outside counsel noted that neither Texas law (where Enron was headquartered) nor federal statutes provided Watkins any protection. Senators became outraged when this letter became public, noting, 'after this high level employee at Enron reported improper accounting practices, Enron did not consider firing [Arthur] Andersen [Enron's accountant]; rather, the company sought advice on the 
manipulation of its financial statements, and when she did so, Enron tried to fire her. ${ }^{8}$ The fact that she received little protection from such adverse employment action incentivized Congress to create the whistleblower protections under SOX. ${ }^{9}$ Congress determined that in order to encourage whistleblowers to come forward with valuable information, it needed to create provisions that explicitly protected them.

SOX's provisions are wide-ranging, and include extended protection for whistleblowers against retaliation for providing inside tips. ${ }^{10}$ Generally, SOX protects six types of illegal conduct. ${ }^{11}$ But, to provide better protection to whistleblowers, SOX affords employees of publically traded companies who report violations a private right of action for retaliation against their employers. ${ }^{12}$ One scholar noted that the main idea behind SOX's anti-retaliation provision is "to motivate employees' to blow the whistle 'by providing employees who make complaints with protection from employer retaliation in the workplace."'13

Sections 301 and 806 of SOX contain the whistleblower provisions. ${ }^{14}$ Section 301 creates a confidential, internal employee reporting system that serves to identify fraud by identifying instances of questionable conduct in accounting and auditing. ${ }^{15}$ Under $\S 301$, publicly traded companies are required to establish audit committees, which in turn, are required to establish procedures by which to accept employee complaints about questionable accounting or auditing matters. ${ }^{16}$ Section 806 creates criminal and civil liability for any company that retaliates against a whistleblower,

\footnotetext{
legality of discharging the whistleblower.' As a result, Congress included expansive whistleblower provisions in the Sarbanes-Oxley Act of 2002.").

$8 \quad I d$.

$9 \quad I d$.

10 See A Price Worth Paying?, supra note 6. Some of these wide-ranging provisions included: establishing the accounting oversight board, prohibiting audit firms from engaging in non-audit work for their clients, requiring companies to establish independent audit committees, forbidding companies from loaning to its own executives, requiring top executives to certify company accounts, making managers responsible for maintaining an adequate internal structures and procedures for financial reporting, and requiring auditors to attest to management's assessment of the company's financial status while disclosing any material weaknesses. See id.

11 See id. SOX's anti-retaliation provision protects employees who provide information or assist in an investigation regarding conduct which the employee reasonably believes to be a violation of $\S \S$ 1341 (fraud and swindles), 1343 (fraud by wire radio or television), 1344 (bank fraud), 1348 (securities and commodities fraud), any rule of the SEC, or any federal law relating to fraud against shareholders. See 18 U.S.C. $\S 1514$ A.

12 See Moberly, supra note 2, at 7.

13 Geoffrey Christopher Rapp, Mutiny by the Bounties? The Attempt to Reform Wall Street by the New Whistleblower Provisions of the Dodd-Frank Act, 2012 BYU L. REV. 73, 82 (2012).

14 See Desai, supra note 5, at 443.

15 See 15 U.S.C. § 78j-1(m)(1) (2010); Desai, supra note 5, at 443.

16 See 15 U.S.C. $\S 78 \mathrm{j}-1(\mathrm{~m})(2010)$.
} 
including those reporting under $\S 301$, and provides remedies for those whistleblowers that are retaliated against. ${ }^{17}$ Specifically, $\S 806$ states that an employer may not "discharge, demote, suspend, threaten, harass, or in any other manner discriminate against an employee in the terms and conditions of employment because of any lawful act done by the employee." 18 The statute defines those lawful acts as:

[P]rovid[ing] information... or otherwise assist[ing] in an investigation regarding any conduct which the employee reasonably believes constitutes a violation of section 1341,1343, 1344, or 1348, any rule or regulation of the Securities and Exchange Commission, or any provision of Federal law relating to fraud against shareholders ... [or] to file, cause to be filed, testify, participate in, or otherwise assist in a proceeding filed or about to be filed (with any knowledge of the employer) relating to an alleged violation. ${ }^{19}$

SOX does not automatically grant a whistleblower direct access to the courts. To bring a retaliation claim, SOX requires that a whistleblower first file a complaint with the United States Secretary of Labor, which delegates authority to handle such claims to the Occupational Safety and Health Administration ("OSHA"). ${ }^{20}$ If OSHA finds in favor of the whistleblower, it may offer a broad range of remedies. ${ }^{21}$ If either party appeals the OSHA decision, an Administrative Law Judge ("ALJ") may review the issue de novo. ${ }^{22}$ In turn, the ALJ's ruling can be appealed under an Administrative Review Board ("ARB"), and after that, to a federal circuit court of appeals. ${ }^{23}$ An additional option given to a whistleblower under SOX is to withdraw the claim from the ARB and to submit it to a federal district court for de novo review. ${ }^{24}$ Remedies available to the plaintiff include the following: reinstatement, standard back pay, and special damages. ${ }^{25}$

After SOX was enacted, many remarked how its whistleblower provisions were the most progressive yet. ${ }^{26}$ Although SOX was lauded

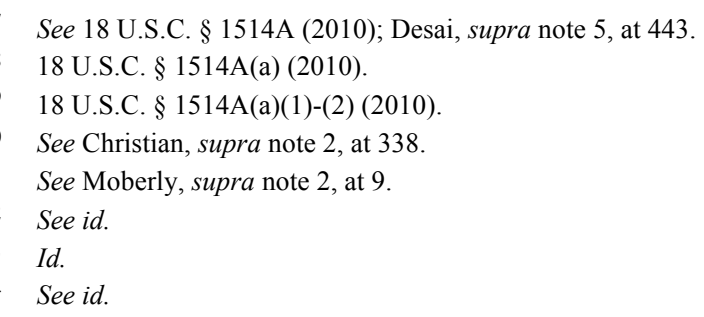

25 See 18 U.S.C. § 1514A(c)(2)(A)-(C) (2010) (compensatory damages under SOX include: "reinstatement with same seniority status that the employee would have had, but for the discrimination; the amount of back pay, with interest; and compensation for any special damages sustained as a result of discrimination, including litigation costs, expert witness fees, and reasonable attorney fees.").

26 Moberly, supra note 2, at 9-10 ("Professor Vaughn called it 'the most important whistleblower protection law in the world,'... and Professor Cynthia Estlund labeled it the 'gold 
after its creation as being an improvement on whistleblower laws, ${ }^{27}$ critics remarked that SOX "gives the illusion of protection without truly meaningful opportunities or remedies for achieving it." ${ }^{28}$ Critics claim that SOX is missing a financial incentive ${ }^{29}$ and that it fails to provide any real motivation for potential whistleblowers to provide information to outside authorities; therefore, SOX does not offer radical reform. ${ }^{30}$ In addition, critics noted that the procedural complexities of bringing a retaliation claim coupled with the brief statute of limitations resulted in very few whistleblowers being awarded a positive outcome on their retaliation claims. ${ }^{31}$ For those that did win claims, the remedies were considered weak and often failed to compensate whistleblowers for the retaliation that was inflicted upon them. ${ }^{32}$

\section{B. The Dodd-Frank Act of 2010}

Similar to SOX, the Dodd-Frank Act ("Dodd-Frank") was enacted in response to a major financial crisis in the United States. ${ }^{33}$ In 2010,

standard' of whistleblower protection. Taxpayers Against Fraud called Sarbanes-Oxley 'the single most effective measure possible to prevent recurrences of the Enron debacle and similar threats to the nation's financial markets,' while Tom Devine of the Government Accountability Project, a whistleblower advocacy group, described the Act as 'the promised land... [T] he law represents a revolution in corporate freedom of speech [that] far surpasses, indeed laps, the rights available for government workers.' The press fueled expectations as well. For example, in 2002, Business Week stated that the Act 'gives those who report corporate misconduct sweeping new legal protection ... [W]histleblowers are going to find life a bit easier."”).

27 See id. at 10.

28 Terry Morehead Dworkin, Sox and Whistleblowing, 105 MICH. L. REV. 1757, 1764 (2007).

29 See Rapp, supra note 13 , at 85.

30 See Lucienne M. Hartmann, Whistle While You Work: The Fairytale-Like Whistleblower Provisions of the Dodd-Frank Act and the Emergence of "Greedy," the Eighth Dwarf, 62 MERCER L. REV. 1279, 1285 (2011).

31 See Dworkin, supra note 28, at 1764-65 ("In a study conducted by Professors Earle and Madek, they report that through May 2006, of the 677 completed Sarbanes-Oxley complaints, 499 were dismissed and 95 were withdrawn. This demonstrates that, at the least, success at this level is an uphill battle. Of the cases that went to an administrative law judge ('ALJ'), only 6 (two percent) of the 286 resulted in a decision for the employee."); Moberly, supra note 2, at 28-29 ("3.6\% of all claimants won after an OSHA investigation - a paltry amount and lower than almost any other comparable statute. To put that in real numbers, by July 13, 2005 (almost exactly three full years after Sarbanes-Oxley's enactment), OSHA issued 361 Sarbanes-Oxley decisions and thirteen claimants won. While these numbers seem low, the numbers have been even worse for whistleblowers since the study ended. From that point until December 31, 2011, more than six years later, only ten more whistleblowers won a case in front of OSHA. In total, from the Act's effective date until the end of 2011 , employees won $1.8 \%$ of the 1,260 cases OSHA decided. Remarkably, for three straight years between fiscal years 2006 and 2008, OSHA did not decide a single case in favor of a Sarbanes-Oxley claimant. During that time, OSHA found for employers in 488 straight decisions.")

32 See Dworkin, supra note 28, at 1764-65; Moberly, supra note 2, at 27 ("Unfortunately, even if Sarbanes-Oxley encouraged employees to report more frequently, the Act often failed to protect them from reprisals and failed to compensate them consistently for the retaliation they suffered.").

33 See Desai, supra note 5, at 444-47. 
Congress enacted Dodd-Frank in response to the 2008 recession and housing market crisis, which can be briefly described as follows:

In 2008 the world economy faced its most dangerous crisis since the Great Depression of the 1930s. The contagion, which began in 2007 when sky-high home prices in the United States finally turned decisively downward, spread quickly, first to the entire U.S. financial sector and then to financial markets overseas. The casualties in the United States included a) the entire investment banking industry, b) the biggest insurance company, c) the two enterprises chartered by the government to facilitate mortgage lending, d) the largest mortgage lender, e) the largest savings and loan, and f) two of the largest commercial banks. The carnage was not limited to the financial sector, however, as companies that normally rely on credit suffered heavily. The American auto industry, which pleaded for a federal bailout, found itself at the edge of an abyss. Still more ominously, banks, trusting no one to pay them back, simply stopped making the loans that most businesses need to regulate their cash flows and without which they cannot do business. Share prices plunged throughout the world - the Dow Jones Industrial Average in the U.S. lost $33.8 \%$ of its value in 2008 - and by the end of the year, a deep recession had enveloped most of the globe. In December the National Bureau of Economic Research, the private group recognized as the official arbiter of such things, determined that a recession had begun in the United States in December 2007, which made this already the third longest recession in the U.S. since World War II. ${ }^{34}$

The causes of the crisis revolve around the following: the fact that many large institutional investors invested in mortgage backed securities ("MBS") with little knowledge of their risks; that many of the borrowers of the underlying mortgages could no longer meet their loan obligationsperhaps due to predatory lending practices which led these borrowers to take advantage of seemingly good credit terms; the fact that credit rating agencies approved the MBS, which increased investor confidence in the investment form; the holding of credit default swaps in connection with such MBS; and the fact that large American financial institutions were so critical to the economy, the failure of which would lead to catastrophic outcomes, led to government bailouts of such firms (often called "too big to fail"). ${ }^{35}$

34 Joel Havemann, The Financial Crisis of 2008: Year in Review 2008, ENCYCLOPEDIA BRITANNICA, http://www.britannica.com/EBchecked/topic/1484264/The-Financial-Crisis-of-2008-YearIn-Review-2008 (last visited Feb. 15, 2015).

35 See Lori Schock, Outline of Dodd-Frank Act and JOBS Act, U.S. SECURITIES \& EXCHANGE 
Dodd-Frank was created to address flaws in the regulatory structure surrounding the events that took place and that led to the crisis with hopes of increasing accountability within the financial system, ensuring financial stability, and decreasing bailouts. ${ }^{36}$ Dodd-Frank affects almost every aspect of the U.S. financial system and has been described as a "sweeping overhaul of our financial system.",37

Dodd-Frank's sweeping provisions include protection for whistleblowers. Dodd-Frank defines a whistleblower as "any individual who provides, or 2 or more individuals acting jointly who provide, information relating to a violation of the securities laws to the Commission, in a manner established, by rule or regulation, by the Commission." 38 The anti-retaliation provision of Dodd-Frank provides as follows:

No employer may discharge, demote, suspend, threaten, harass, directly or indirectly, or in any other manner discriminate against, a whistleblower in the terms and conditions of employment because of any lawful act done by the whistleblower-

(i) in providing information to the Commission in accordance with this section;

(ii) in initiating, testifying in, or assisting in any investigation or judicial or administrative action of the Commission based upon or related to such information; or

(iii) in making disclosures that are required or protected under the Sarbanes-Oxley Act of 2002 (15 U.S.C. 7201 et seq.), this chapter, including section $78 \mathrm{j}-1(\mathrm{~m})$ of this title, section 1513(e) of Title 18, and any other law, rule, or regulation subject to the jurisdiction of the Commission. ${ }^{39}$

The last section of the anti-retaliation provision, section (iii), has come to be a source of great controversy within the courts, and will be referred to throughout this Comment as the "Third Section."

Dodd-Frank partly amended SOX and also created alternative forms of action that coincide with SOX. ${ }^{40}$ Dodd-Frank amended $\S 806$ of SOX to specifically cover a publicly traded company's subsidiaries, including those

COMMission (June 9, 2012), http:/www.sec.gov/News/Speech/Detail/Speech/1365171490596\#.VK9 MfSvF-AU

36 See Shannon Kay Quigley, Whistleblower Tug-of-War: Corporate Attempts to Secure Internal Reporting Procedures in the Face of External Monetary Incentives Provided by the Dodd-Frank Act, 52 SANTA ClARA L. REV. 255, 267 (2012); Schock, supra note 35.

37 See Schock, supra note 35.

3815 U.S.C. $\$ 78 u-6$ (a)(6) (2010).

3915 U.S.C. $\S 78 \mathrm{u}-6$ (h)(1)(a) (2010).

40 See Hartmann, supra note 30 , at 1286. 
that are privately held. ${ }^{41}$ Dodd-Frank doubled the statute of limitations for whistleblowers to bring a retaliation claim under SOX from ninety to one hundred and eighty days. ${ }^{42}$ Dodd-Frank also prohibited employee waivers and pre-dispute arbitration agreements regarding whistleblowers' antiretaliation protections. ${ }^{43}$

In comparison to SOX, Dodd-Frank offers significant benefits and incentives for whistleblowers. Overall, Dodd-Frank creates a greater incentive for a whistleblower to report concerns and makes it easier for a whistleblower to bring a retaliation claim. ${ }^{44}$ Generally, Dodd-Frank does three things differently from SOX: first, Dodd-Frank offers a broader scope of actions that are protected against retaliation; second, SOX requires exhausting an administrative process before bringing a claim to federal court while Dodd-Frank actions may be brought directly to a United States district court; third, Dodd-Frank provides for more extensive remedies. ${ }^{45}$ Section 922 of Dodd-Frank creates a new private right of action for whistleblowers that are retaliated against which, unlike SOX, allows whistleblowers to bring their claims directly in a district court without first having to exhaust administrative remedies under OSHA. ${ }^{46}$ Section 922 of Dodd-Frank also creates a bounty program by which whistleblowers receive a monetary reward of between ten and thirty percent of the overall recovery if the whistleblower provides original information that leads to successful action by the SEC and results in a minimum monetary sanction of one million dollars. ${ }^{47}$

Whistleblowers have a greater incentive to report violations to the SEC based on Dodd-Frank's Bounty Program. ${ }^{48}$ In the event of retaliation, whistleblowers are protected based on Dodd-Frank's anti-retaliation

41 See Rachel Beller, Whistleblower Protection Legislation of the East and West: Can It Really Reduce Corporate Fraud and Improve Corporate Governance? A Study of the Successes and Failures of Whistleblower Protection Legislation in the US and China, 7 N.Y.U. J. L. \& BUS. 873, 914 (2011) (stating that the amendment "eliminate[ed] the often-used defense that publicly traded companies are not liable for the actions of their non-publicly traded subsidiaries"); Hartmann, supra note 30, at 1299.

42 See Moberly, supra note 2, at 16.

43 See 18 U.S.C. § 1514 A(e) (2010).

44 See Desai, supra note 5, at 451.

45 See Hartmann, supra note 30, at 1302-03.

46 See 15 U.S.C.A. $§ 78 \mathrm{u}-6(\mathrm{~h})(1)(B)(\mathrm{i})$; Beller, supra note 41, at 914 (stating that unlike SOX, there is no requirement for the employee to reasonably believe that the reported conduct violates a law, making it more likely that whistleblower claims under Dodd-Frank will progress further during litigation that those brought under SOX).

47 See Beller, supra note 41, at 915.

48 See id. at 914-15. The Bounty Program under Dodd-Frank allows a whistleblower "who voluntarily provide[s] original information to the Commission that [leads] to the successful enforcement of ... [an] action" to receive an award of ten to thirty percent, in total, of what the monetary sanctions imposed in the action. 15 U.S.C. $\S 78 u-6(2010)$. 
[Vol. 10:279

provision and they are adequately rewarded for winning retaliation claims, where they may receive reinstatement, double back pay, and reimbursement for attorneys' fees. ${ }^{49}$ Finally, whistleblowers bringing a retaliation claim under Dodd-Frank benefit from an increased statute of limitations, which is six years to bring a retaliation claim from the date of retaliation or three years after the material facts are known. ${ }^{50}$

Many scholars have commented that Dodd-Frank creates a two-tiered system of retaliation protection across SOX and Dodd-Frank because if whistleblowers report to the SEC they receive greater protection, but if they report internally, they may receive less protection. ${ }^{51}$ Generally speaking, "the Dodd-Frank whistleblower program seems to be at odds with the objective of US SOX to strengthen internal corporate compliance programs." ${ }^{, 52}$ The two-tiered system under SOX and Dodd-Frank discourages internal reporting $;{ }^{53}$ however, corporations must maintain the internal reporting controls required by SOX. Though simultaneously, Dodd-Frank offers monetary incentives that directly undermine the purpose of SOX's internal compliance programs. ${ }^{54}$ Therefore, Dodd-Frank essentially weakens the internal compliance system put in place by SOX by discouraging employees to report internally and encouraging them to report directly to the SEC in hopes of receiving a monetary award. ${ }^{55}$ The SEC tried to address such concerns by implementing policies to encourage internal reporting first, but there is no indication that such policies do, in fact, encourage internal reporting.

\section{PART II}

After Dodd-Frank's whistleblower provisions were enacted, many employees who internally reported potential violations of securities laws under SOX, and who subsequently suffered adverse employment actions, came forward seeking protection under Dodd-Frank's anti-retaliation provisions. The courts hearing these cases have struggled with the issue of whether whistleblowers making disclosures required by SOX must report the information to the SEC, as opposed to reporting internally, to avail

\footnotetext{
49 See id.; 15 U.S.C. $\S 78 \mathrm{u}-6(\mathrm{~h})(1)(\mathrm{C})(2010)$.

$50 \quad$ See 15 U.S.C. $\$ 78 \mathrm{u}-6(\mathrm{~h})(1)(\mathrm{B})(\mathrm{iii})(2010)$.

51 See Corporate Law-Securities Regulation-Congress Expands Incentives for Whistleblowers to Report Suspected Violations to the Sec. - Dodd-Frank Act, Pub. L. No. 111-203, S 922, 124 Stat. 1376, $1841-49$ (2010) (to be codified at 15 U.S.C. $\$$ 78u-6), 124 HARV. L. REV. 1829, 1830 (2011) [hereinafter Corporate Law-Securities Regulation].

52 Beller, supra note 41, at 915.

53 See Corporate Law-Securities Regulation, supra note 51.

54 See generally Quigley, supra note 36.

55 See id.; Hartmann, supra note 30, at 1307.
} 
themselves of Dodd-Frank's whistleblower provisions. The tension lies in the statutory language of Dodd-Frank; on one hand, Dodd-Frank's definition of a whistleblower clearly states that a whistleblower is one who reports to the SEC, ${ }^{56}$ on the other hand, the anti-retaliation provision of Dodd-Frank provides three categories of action which are protected from retaliation, ${ }^{57}$ the Third Section includes disclosures required by SOX, which can be read as an exception to the general requirement of a Dodd-Frank whistleblower to report to the SEC.

The Fifth Circuit, in Asadi v. GE Energy, ${ }^{58}$ is the only circuit court to hear the issue thus far, and found that whistleblowers making disclosures required by SOX must report to the SEC to avail themselves of retaliation protection under Dodd-Frank. Numerous district courts have heard the issue and have held on both sides-some agree with Asadi, while the majority disagree with Asadi's holding, finding that internal reporting of violations required by SOX are sufficient to state a claim under DoddFrank. For purposes of this Part, the Asadi holding is considered to be the narrow interpretation of the statutory provision at issue, and the contrary view is considered to be the broad interpretation of the statutory provision at issue.

With so much tension, and often times vehemently opposing views, this issue is certain to be heard by more circuit courts in the future, and, if a circuit split ensues, may ultimately reach the U.S. Supreme Court. The following Part II, section I, first gives a detailed description of the Fifth Circuit's hearing on this issue in Asadi. Second, Part II, section II reviews the district court's holding on the issue by giving a detailed description on those cases heard prior to Asadi and which found for a broad definition of a whistleblower. Finally, Part II concludes by briefly reviewing the district court cases heard after Asadi.

I. United States Circuit Court of Appeals for the Fifth Circuit-Asadiv. GE Energy ${ }^{59}$

Asadi, the appellant, filed a lawsuit against GE Energy, the appellee, claiming that GE Energy fired him after he made an internal complaint about a possible securities violation. ${ }^{60}$ Asadi had accepted a position to work as GE Energy's Iraq Country Executive and moved to Jordan. While there, Iraqi officials notified Asadi of their concerns that GE Energy had

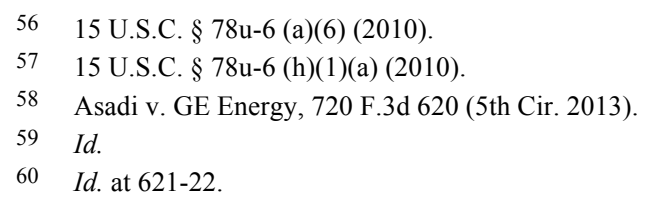


[Vol. 10:279

"hired a woman closely associated with a senior Iraqi official to curry favor with that official in negotiating a lucrative joint venture agreement." 61 Asadi suspected that this behavior was a violation of the Foreign Corrupt Practices Act ("FCPA") and reported it to his supervisor and to the ombudsperson for the region. ${ }^{62}$ Shortly thereafter, Asadi received a negative performance evaluation and was pressured to step down to a position with minimal responsibility. ${ }^{63}$ Asadi refused to be demoted and was fired approximately one year after making the reports. ${ }^{64}$

In his complaint, Asadi claimed that GE Energy violated DoddFrank's whistleblower anti-retaliation provisions when it fired him subsequent to his internal reports about possible FCPA violations. ${ }^{65} \mathrm{GE}$ Energy moved to dismiss the complaint on two grounds: (1) that DoddFrank's whistleblower provisions do not apply extraterritorially; and (2) that Asadi does not qualify as a whistleblower under the Act because he did not report his claims to the SEC. ${ }^{66}$ The district court granted GE Energy's motion to dismiss based on failure to state a claim due to the fact that the whistleblower provision does not apply to extraterritorial activity, but did not decide whether Asadi qualified as a whistleblower under Dodd-Frank. ${ }^{67}$ Asadi subsequently appealed. ${ }^{68}$ The only issue on appeal was the interpretation of Dodd-Frank and was reviewed de novo. ${ }^{69}$

The Fifth Circuit framed the issue as "whether an individual who is not a 'whistleblower' under the statutory definition... may, in some circumstances, nevertheless seek relief under the whistleblower-protection provision." ${ }^{, 70}$ The Asadi court found that Dodd-Frank's whistleblower retaliation protection applies only to those who report to the SEC, and because Asadi did not report to the SEC, he did not have a claim. ${ }^{71}$ The Fifth Circuit recognized the prior case law at the district court level in favor of Asadi's position, ${ }^{72}$ but stated that those constructions relied on a

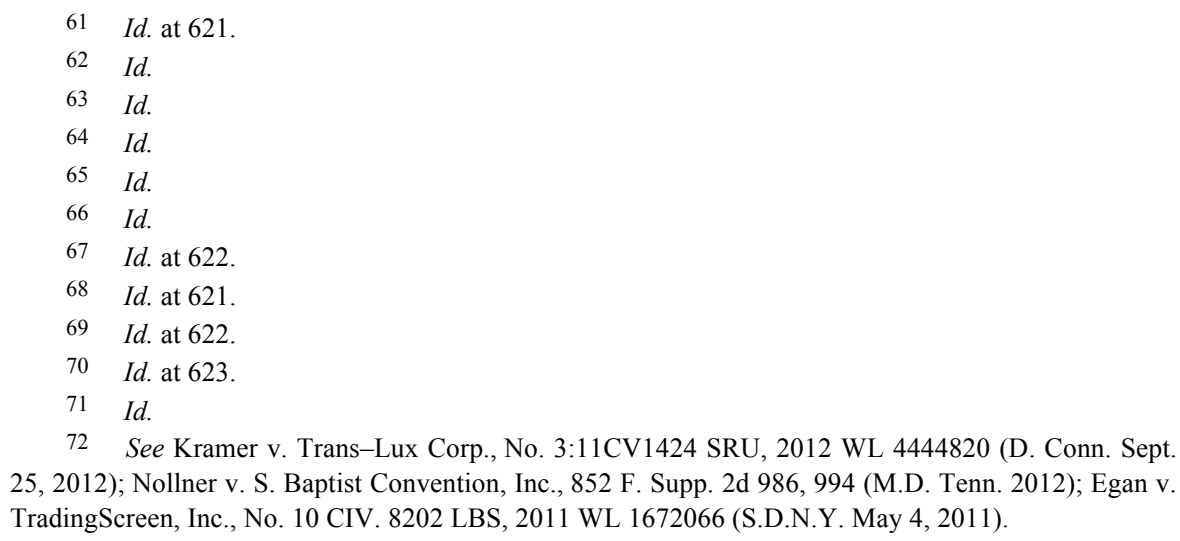


misreading of Dodd-Frank's statutory provisions. ${ }^{73}$

Finding that there was no ambiguity in the statutory language, the court looked only at the text of the statute. ${ }^{74}$ The Asadi court first looked at Dodd-Frank's definition of whistleblower and found that the definition alone "expressly and unambiguously requires that an individual provide information to the SEC to qualify as a "whistleblower." 75 The court then compared the anti-retaliation provision. ${ }^{76}$ Asadi's contention was that the Third Section under the anti-retaliation provision conflicts with the definition of whistleblower and does not require disclosure to the SEC. ${ }^{77}$ However, the Fifth Circuit declined to agree with Asadi's analysis and noted that the conflict only results if it were to read the three categories as types of whistleblowers. ${ }^{78}$ Instead, the Asadi court interpreted the statute as follows: under the plain language and structure, there is only one category of whistleblower, which accords to the definition in the statute, and the three categories represent the types of actions that, when taken by the whistleblower, are protected. $^{79}$ The Asadi court stated that the Third Section, or type of action, is not superfluous because it "protects those individuals who qualify as whistleblowers from retaliation on the basis of other required or protected disclosures." ${ }^{\prime 0}$

The Asadi court offered another reason as to why it believed that Asadi's construction of Dodd-Frank was problematic. ${ }^{81}$ The Asadi court stated that extending protection beyond the statutory definition would effectively render SOX moot because an individual who makes a claim under SOX could also make a claim under Dodd-Frank on the basis that SOX protected the disclosure. However, it is unlikely that any plaintiff would choose to bring a claim under SOX as opposed to Dodd-Frank because Dodd-Frank offers much more plaintiff friendly provisions. ${ }^{82}$

73 Asadi, 720 F.3d at 624-30.

74 Id. A precursor to using statutory interpretation is to determine whether the plain language of the statute is ambiguous. If it is not, then only the text of the statute will be analyzed. See infra Part III.

75 Asadi, 720 F.3d at 623. Dodd-Frank defines a whistleblower as "any individual who provides, or 2 or more individuals acting jointly who provide, information relating to a violation of the securities laws to the Commission, in a manner established, by rule or regulation, by the Commission." 15 U.S.C. $\S 78 \mathrm{u}-6(\mathrm{a})(6)(2010)$

76 Asadi, 720 F.3d at 623.

77 Id. at 624 .

78 Id. at 626.

79 Id. at 625.

$80 \quad I d$. at 628.

81 Id.

$82 I d$. 
[Vol. 10:279

\section{United States District Court Cases}

The following sub-sections first describe in detail the three district court cases decided before Asadi that found for a broad interpretation of the relevant statutory provisions. Second, these sub-sections give a brief overview of the district court cases that were heard post-Asadi.

\section{A. Pre-Asadi Cases}

\section{i. Egan v. TradingScreen, Inc. ${ }^{83}$}

Egan, the plaintiff, was an employee of the defendant company, TradingScreen. Egan learned that the CEO of TradingScreen was diverting TradingScreen's assets to another company, which the CEO owned solely. ${ }^{84}$ Egan also claimed that the CEO was using TradingScreen's employees to do unpaid work for the solely owned company, was cannibalizing TradingScreen's customer lists, and was invoicing at below-market rates. ${ }^{85}$ Egan claimed that this was costing TradingScreen hundreds of thousands of dollars and was a threat to the business. ${ }^{86}$ Egan reported this information to the president, who reported it to the board of directors. ${ }^{87}$ The board hired a law firm to do an internal investigation, which corroborated Egan's claims. ${ }^{88}$ The board attempted to get the CEO to resign, but the CEO gained control of the board and in turn did not resign. ${ }^{89}$ The CEO then fired Egan. ${ }^{90}$ Egan claimed that the CEO violated the anti-retaliation provision of Dodd-Frank when he fired him. ${ }^{91}$ TradingScreen claimed that Egan was not eligible to bring a retaliation claim under Dodd-Frank because he did not report his complaint directly to the SEC. ${ }^{92}$

The Southern District of New York held that the plaintiff could not bring a claim because the company was privately held, where a public company is required to bring a claim under Dodd-Frank. ${ }^{93}$ But, the Egan court nevertheless analyzed whether, in regard to a public company, a claim could be brought under Dodd-Frank's retaliation provision if the plaintiff reported internally as opposed to the SEC. The court stated in dicta that a

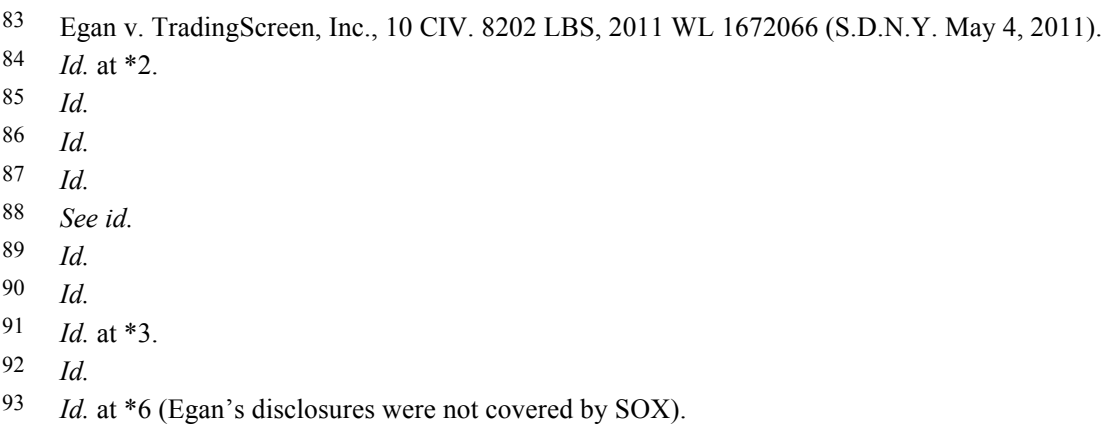


plaintiff can bring a Dodd-Frank retaliation claim even if he or she did not report to the SEC. ${ }^{94}$

Only the Third Section of the anti-retaliation provision was at issue. ${ }^{95}$ The Egan court engaged in statutory construction and first found that the provision at issue was ambiguous because "a literal reading of the definition of the term 'whistleblower'..., requiring reporting to the SEC, would effectively invalidate [the Third Sections]'s protection of whistleblower disclosures that do not require reporting to the SEC." 96 The court first looked at legislative history of the act, but found that very little exists. The court stated that the principles of statutory construction dictate that no phrase or word shall be left superfluous when rendering a meaning for a statute. $^{97}$ To reconcile this canon of statutory construction, the court found that the Third Section is a narrow exception to Dodd-Frank's general definition of a whistleblower. ${ }^{98}$ Therefore, to avail oneself of Dodd-Frank's anti-retaliation provisions, the court found that one must either report to the SEC or claim that his or her disclosures fell under the Third Section, which does not require reporting to the SEC. ${ }^{99}$

\section{ii. Nollner v. South Baptist Convention, Inc. ${ }^{100}$}

Nollner, the plaintiff, took a job offer to move to New Delhi for a term of twenty-four to thirty-six months to perform missionary work and manage the construction of a new office building, where his wife would also be employed. ${ }^{101}$ Both husband and wife quit their jobs to take the new positions. ${ }^{102}$ When plaintiff and his wife arrived in New Delhi, the situation was not as they expected and they noticed some troubling issues at the site, including: an absence of a bidding process for companies (the firms chosen were owned by one individual); the corporation was operating through dummy companies to conceal the nature of its operations; there were incomplete records for invoices and payment; the contractor and the

94 Id. at *7 ("In sum, the anti-retaliation whistleblower protection provisions of the Dodd-Frank Act require Plaintiff to show that he either provided information to the SEC, or that his disclosures fell under the four categories listed in 15 U.S.C. $\S 78 \mathrm{u}-6(\mathrm{~h})(1)(\mathrm{A})(\mathrm{iii})$. Since Plaintiff fails to allege the latter, he must establish the former.").

$95 I d$. at *8. The specific provision at issue was $\S 76 \mathrm{u}-6(\mathrm{~h})(1)(\mathrm{A})(\mathrm{iii})$.

96 Id. at $* 4$.

$97 \quad$ Id. at $* 5$.

$98 \quad I d$.

99 Id. at $* 5$ (which includes disclosures required or protected under SOX, the Securities Exchange Act of 1934, $\S 1513$ (e) of title 18 of the United States Code, or any other regulation subject to the jurisdiction of the Commission).

100 Nollner v. S. Baptist Convention, Inc., 852 F. Supp. 2d 986 (M.D. Tenn. 2012).

101 Id. at 989.

102 Id 
[Vol. 10:279

architect tried to bribe the plaintiff after he complained about their performances; the contractor and the architect were paying bribes to local officials; and they had obtained an improper or illegal permit. ${ }^{103}$ Nollner reported his concerns to his supervisors and fellow employees multiple times, and each time was ignored. ${ }^{104}$ Subsequently, Nollner was asked to resign, but refused and was eventually fired. ${ }^{105}$ Nollner filed a complaint under Dodd-Frank's anti-retaliation provisions claiming that he was eligible as a whistleblower for reporting concerns about the Foreign Corrupt Practices Act ("FCPA"). ${ }^{106}$

The Nollner court held that Nollner could not bring a claim under Dodd-Frank because the FCPA is not under the jurisdiction of the SEC, but is instead under the Department of Justice. ${ }^{107}$ But, the court analyzed whether the Third Section of the anti-retaliation provision requires a report to be made directly to the SEC. ${ }^{108}$ The Nollner court found that the Third Section does not require a whistleblower to report to the SEC directly, but only that the disclosure was required by certain laws within the SEC's jurisdiction. ${ }^{109}$ The court stated, "[w]ith respect to the scope of [the Third Section], the 'catch-all' anti-retaliation protections extend only to any 'law, rule, or regulation subject to the jurisdiction of the Commission." "110 The court also applied statutory construction, stating that it "must, if possible, give reasonable meaning to the Act's terms without rendering any of the language superfluous." 111 Accordingly, the court found as follows:

[The Third Section] of the anti-retaliation provisions [must be read] in conjunction with the definition of whistleblower, which protects an individual from retaliation for reporting "information relating to a violation of the securities laws." Thus, harmonizing these provisions, a plaintiff seeking relief under anti-retaliation provision part (iii) must demonstrate that the disclosure at issue relates to a violation of federal securities laws. Furthermore, anti-retaliation provision part (iii) only protects disclosures that are "required or protected" by laws, rules, or regulations within the SEC's jurisdiction. Thus, an employee is not protected from retaliation if the disclosure at issue-even if relates to an actual legal violation by the employer-concerns a disclosure that

\footnotetext{
103 Id. at 989-90.

104 Id. at 990.

105 Id.

106 Id

107 Id. at 996

108 Id. at 993.

109 Id. at 994.

110 Id

111 Id
} 
is not "required" or otherwise "protected" by a law, rule, regulation within the SEC's jurisdiction. ${ }^{112}$

Thus, the Nollner court, following the Egan court, also found that when reporting violations under the Third Section, a plaintiff is not required to report that information directly to the SEC.

\section{iii. Kramer v. Trans-Lux Corporation ${ }^{113}$}

Kramer, the plaintiff, worked for the defendant, Trans-Lux, for eighteen years as Vice President of human resources and administration. ${ }^{114}$ Kramer advised the CFO that the company required three people on the pension plan committee, of which it had only two people at the time. ${ }^{115}$ The CFO was one of the people on this committee and was also the sole trustee for the pension plan. ${ }^{116}$ Kramer believed this created a conflict of interest and reported his concerns internally. ${ }^{117}$ Changes were made to the pension plans under the two-person committee, which required three people for a decision to be made. ${ }^{118}$ The CFO was also required to bring some amendments to the board of directors in addition to reporting them to the SEC, but failed to do either. ${ }^{119}$ The CFO also ordered Kramer not to file a form to the SEC, which would have disclosed the failure and would have subjected the company to a fine. ${ }^{120}$ After reporting his concerns to the board of directors, Kramer was stripped of many of his duties and eventually fired. ${ }^{121}$

The court found that Kramer had alleged sufficient facts to support a claim under Dodd-Frank even though he did not report to the SEC. ${ }^{122}$ The court first found that the statute was ambiguous and noted, in regard to reading the statute narrowly: "[s]uch a reading seems inconsistent with the goal of the Dodd-Frank Act, which was to 'improve the accountability and transparency of the financial system,' and create 'new incentives and

112 Id.; Egan v. TradingScreen, Inc., 10 CIV. 8202 LBS, 2011 WL 1672066, *6 (S.D.N.Y. May 4,2011 ) (" $[\mathrm{M}]$ erely alleging the violation of a law or rule under the SEC's purview is not enough; a plaintiff must allege that a law or rule in the SEC's jurisdiction explicitly requires or protects disclosure of that violation.").

113 Kramer v. Trans-Lux Corp., 3:11CV1424 SRU, 2012 WL 4444820 (D. Conn. Sept. 25, 2012).

$114 I d$. at *2

115 Id.

116 Id.

117 Id. at *2-3.

$118 I d$. at *2.

119 Id.

120 Id

$121 I d$. at *3.

122 Id. at *7. 
protections for whistleblowers."123 The court next looked to the SEC's rule and determined that it was a permissible construction of Dodd-Frank. ${ }^{124}$ The Court referenced Egan and Nollner in stating that both have held that the Third Section calls for a broad construction of the term whistleblower, and found in accordance with those prior decisions. ${ }^{125}$

\section{B. Post-Asadi Cases in Disagreement with Asadi}

Since Asadi was decided in 2013, at least eight district court cases have disagreed with the holding in Asadi. Overall, these cases find that the statutory provisions at issue are ambiguous. ${ }^{126}$ The cases apply various canons of statutory interpretation to arrive at a broad interpretation, finding that a whistleblower reporting disclosures required by SOX does not need to report to the SEC to avail him or herself of Dodd-Frank's anti-retaliation provisions. These courts have found that little legislative history exists on this issue, but they all agree that Congress's intent was unlikely to exclude a whistleblower from protection under Dodd-Frank for reporting SOX violations internally and not directly to the SEC. ${ }^{127}$ One court looked at the definition of a whistleblower itself and found that if applying a definition to a statutory provision would defeat the provision's purpose, the court would not mechanically apply that definition. ${ }^{128}$ Finally, the majority of these cases tend to defer to an administrative agency's interpretation under the Chevron analysis-relying on the SEC's statement that a whistleblower under the Third Section need not report directly to the SEC. ${ }^{129}$ One court even goes so far as to state that a narrow construction of Dodd-Frank would render the Third Section moot. ${ }^{130}$ This is the majority view on the issue as those courts which find for a broad interpretation heavily outweigh those

$123 I d$. at $* 4$

124 Id. at *5; see infra Part III.

125 Kramer, 2012 WL 4444820, at *4-5.

126 See Rosenblum v. Thomson Reuters (Markets) LLC, 984 F. Supp. 2d 141, 147 (S.D.N.Y. 2013); Connolly v. Remkes, No. 5:14-CV-01344-LHK, 2014 WL 5473144, at *6 (N.D. Cal. Oct. 28, 2014); Khazin v. TD Ameritrade Holding Corp., No. CIV.A. 13-4149 SDW, 2014 WL 940703, at *6 (D.N.J. Mar. 11, 2014) aff'd on other grounds, 773 F.3d 488 (3d Cir. 2014); Genberg v. Porter, 935 F. Supp. 2d 1094, 1106 (D. Colo. 2013) aff'd in part, appeal dismissed in part, 566 F. App'x 719 (10th Cir. 2014); Murray v. UBS Sec., LLC, No. 12 CIV. 5914 JMF, 2013 WL 2190084, at*4 (S.D.N.Y. May 21, 2013)

127 Bussing v. COR Clearing, 20 F. Supp. 3d 719, 730 (D. Neb. 2014); Connolly, 2014 WL 5473144 , at $* 6$.

128 Bussing, 20 F. Supp. 3d at 729.

129 See Ellington v. Giacoumakis, 977 F. Supp. 2d 42, 45 (D. Mass. 2013); Rosenblum, 984 F. Supp. 2d at 146-47; Connolly, 2014 WL 5473144, at*6; Khazin, 2014 WL 940703, at*6; Murray, 2013 WL 2190084, at *4; Yang v. Navigators Grp., Inc., No. 13-CV-2073 NSR, 2014 WL 1870802 (S.D.N.Y. May 8, 2014). For a better analysis of the Chevron rule as applied to this issue and for the text of the SEC's rule on this issue, see infra Part III.

130 Genberg, 935 F. Supp. 2d at 1106. 
that find for a narrow interpretation.

\section{Post-Asadi Cases in Agreement with Asadi}

Those post-Asadi cases that agree with Asadi's holding all find that Dodd-Frank's anti-retaliation provision is not ambiguous. ${ }^{131}$ These courts find that only a whistleblower who reports directly to the SEC is protected under all three prongs of Dodd-Frank's anti-retaliation provision. ${ }^{132}$ One court goes so far as to acknowledge the fact that numerous courts are in disagreement about how to interpret the statute, but stated that just because numerous courts disagree does not automatically render the statute ambiguous. ${ }^{133}$ Because these courts find that the statute is unambiguous, they look only at the plain language of the statute. ${ }^{134}$ In applying the plain language of the statute, all of these courts find that there is no separate definition of a whistleblower ${ }^{135}$ under the Third Section and that Congress intended for a Dodd-Frank whistleblower to report directly to the SEC. ${ }^{136}$

Some of the courts analyze canons of statutory construction to claim support for not applying a broad definition of the term whistleblower. They find that by allowing a whistleblower who has not reported to the SEC to bring a claim under the anti-retaliation provisions titled "Protection of Whistleblower" would violate that section's heading, which indicates it is only for whistleblowers. ${ }^{137}$ Allowing a broad definition would also ignore the plain language of the statute and would not give effect to every word because it would render the words "to the commission" superfluous. ${ }^{138}$ Some of the courts also briefly address the SEC's interpretation on the issue, stating that it should not even be considered given that the statute is not ambiguous on its face, ${ }^{139}$ and noting that even if they were to apply the SEC's interpretation, it would render the entire definitional section of the Act superfluous. ${ }^{140}$

131 Englehart v. Career Educ. Corp., No. 8:14-CV-444-T-33EAJ, 2014 WL 2619501, at *7 (M.D. Fla. 2014); Berman v. Neo@Ogilvy LLC, No. 1:14-CV-523-GHW-SN, 2014 WL 6860583, at*2 (S.D.N.Y. Dec. 5, 2014); Banko v. Apple, Inc., 20 F. Supp. 3d 749, 756 (N.D. Cal. 2013); Verfuerth v. Orion Energy Systems, Inc., No. 14-C-352, 2014 WL 5782514, at*3 (E.D. Wis. 2014).

132 Verfuerth, 2014 WL 5782514, at*3.

133 Englehart, $2014 \mathrm{WL} 2619501$, at *8.

134 Wagner v. Bank of Am. Corp., No. 12-CV-00381-RBJ, 2013 WL 3786643, at *5 (D. Colo. 2013).

135 Id.

136 Englehart, 2014 WL 2619501, at*7.

137 Id. at *8.

138 Banko v. Apple, Inc., 20 F. Supp. 3d 749, $756-57$ (N.D. Cal. 2013).

139 Id. at 757

140 Verfuerth v. Orion Energy Sys., Inc., No. 14-C-352, 2014 WL 5782514, at *3 (E.D. Wis. 2014); see generally 17 C.F.R. $\S \S 240,249$. For an analysis of the SEC's rule on the issue see infra Part III. 
Many of the courts also subscribe to and cite Asadi's mootness argument - stating that if the definition of whistleblower were interpreted broadly, SOX would be rendered moot because no person would sue under SOX given the more favorable provisions of Dodd-Frank. ${ }^{141}$ Finally, these courts note that they have no issue prohibiting a whistleblower, who reported internally only, from receiving retaliation protection under DoddFrank because that whistleblower has an outlet under SOX and should use it if needed. ${ }^{142}$ This holding is the minority view. ${ }^{143}$

\section{PART III}

Dodd-Frank's anti-retaliation provisions should be interpreted by courts to find that whistleblowers who make disclosures required by SOX, do not have to first report to the SEC to avail themselves of Dodd-Frank's anti-retaliation provisions. There are two primary reasons why courts should find for a broad definition of whistleblowers: (1) the traditional canons of statutory interpretation lead to this result; and (2) public policy weighs in favor of finding this result.

\section{Statutory Interpretation}

Statutory interpretation, also referred to as statutory construction, is the process that courts use to interpret and apply a statute. The first step in interpreting a statute is to determine whether the statute has plain meaning or whether it is clear and unambiguous. ${ }^{144}$ If the text of the statute has plain meaning or is unambiguous, then the "inquiry begins and ends with the text." 145 No further analysis is required and that statute is applied as it is written - the court should not consider even legislative history or purpose

141 Wagner v. Bank of Am. Corp., No. 12-CV-00381-RBJ, 2013 WL 3786643, at *6 (D. Colo. 2013); Verfuerth, No. 14-C-352, 2014 WL 5782514, at*4.

142 Berman v. Neo@Ogilvy LLC, No. 1:14-CV-523-GHW-SN, 2014 WL 6860583, at *2 (S.D.N.Y. Dec. 5, 2014); Banko, 20 F. Supp. 3d at 757.

143 Wagner, No. 12-CV-00381-RBJ, 2013 WL 3786643, at *6.

144 See Conn. Nat'1 Bank v. Germain, 503 U.S. 249, 253-54 (1992) (citations omitted) ("In any event, canons of construction are no more than rules of thumb that help courts determine the meaning of legislation, and in interpreting a statute a court should always turn first to one, cardinal canon before all others. We have stated time and again that courts must presume that a legislature says in a statute what it means and means in a statute what it says there. When the words of a statute are unambiguous, then, this first canon is also the last: "judicial inquiry is complete." ).

145 Banko v. Apple, Inc., 20 F. Supp. 3d 749, 755 (N.D. Cal. 2013) (citing BedRoc Ltd. v. United States, 541 U.S. 176, 183 (2004)); Barnhart v. Sigmon Coal Co., 534 U.S. 438, 461-62 (2002) ("We have stated time and again that courts must presume that a legislature says in a statute what it means and means in a statute what it says there. When the words of a statute are unambiguous, then, this first canon is also the last: "judicial inquiry is complete."') (citing Germain, 503 U.S. at 253-54) (internal quotations omitted). 
of the statute. ${ }^{146}$ If the text of the statute is ambiguous, courts may use statutory interpretation, which includes canons such as legislative history and administrative regulations, to interpret the meaning of the statute. ${ }^{147}$

\section{A. Step One: Does the Statute have Plain Meaning and Is It Clear and Unambiguous?}

To determine whether a statute has plain meaning and is clear and unambiguous, one must look at "the language itself, the specific context in which that language is used, and the broader context of the statute as a whole." ${ }^{148}$ Ambiguity can be found in a number of ways ${ }^{149}$ - such as when the text is difficult to understand or lacks clarity ${ }^{150}$ or when it is susceptible to more than one reasonable meaning. ${ }^{151}$ Ambiguity can also exist when reasonably well informed persons can interpret the statute to have two different meanings. ${ }^{152}$

Whether the Dodd-Frank anti-retaliation provision is ambiguous is the main contention between the courts. Those that favor a narrow interpretation of the term "whistleblower" find that the statute is unambiguous which automatically precludes any consideration of canons of statutory interpretation. Those courts that find for a broad definition of the term whistleblower find that the statutory provisions are ambiguous and are able to find support for such a broad definition through use of canons of statutory interpretation. Asadi and those courts that follow Asadi's holding are incorrect in finding that no ambiguity exists in the statute. There is ambiguity between the definition of a whistleblower and the Third

\footnotetext{
146 In re Phila. Newspapers, LLC, 599 F.3d 298, 304 (3d Cir. 2010), as amended (May 7, 2010).

147 Cohen v. JP Morgan Chase \& Co., 498 F.3d 111, 116 (2d Cir. 2007); Banko, 20 F. Supp. 3d at 755 .

148 Banko, 20 F. Supp. 3d at 755 (citing Robinson v. Shell Oil Co., 519 U.S. 337 (1997)); Healthkeepers, Inc. v. Richmond Ambulance Auth., 642 F.3d 466, 471 (4th Cir. 2011); Geo-Energy Partners-1983 Ltd. v. Salazar, 613 F.3d 946, 956 (9th Cir. 2010).

149 For a discussion on ambiguity in statutory interpretation see Brian G. Slocum, The Importance of Being Ambiguous: Substantive Canons, Stare Decisis, and the Central Role of Ambiguity Determinations in the Administrative State, 69 MD. L. REV. 791 (2010).

150 Maldonado v. Nutri/Sys., Inc., 776 F. Supp. 278, 282 (E.D. Va. 1991).

151 In re Rogers, 513 F.3d 212, 226 (5th Cir. 2008); In re Phila. Newspapers, LLC, 599 F.3d 298, 304 (3d Cir. 2010), as amended (May 7, 2010) ("A provision is ambiguous only where the disputed language is 'reasonably susceptible of different interpretations."').

152 See Slocum, supra note 149, at 800 ("Other definitions focus on the interpreter rather than the text. One common definition, for example, posits that ambiguity 'exists when a statute is capable of being understood by reasonably well-informed persons in two or more different senses'. .. .); see also In re Price, 370 F.3d 362, 369 (3d Cir. 2004) ("Rather, a provision is ambiguous when, despite a studied examination of the statutory context, the natural reading of a provision remains elusive. In such situations of unclarity, '[w]here the mind labours to discover the design of the legislature, it seizes every thing from which aid can be derived ... .'”) (quoting United States v. Fisher, 6 U.S. 358, 386 (1805)).
} 
Section. ${ }^{153}$ This ambiguity is most prominently highlighted by the fact that it is susceptible to more than one reasonable meaning and that reasonably well-informed persons can interpret the statute in two different ways. Nothing lends more support to this fact than the stark divide between courts in interpreting the statute. Some courts interpret the provisions broadly, while others interpret the provisions narrowly - a complete juxtaposition, which is exemplary of ambiguity. ${ }^{154}$ Finally, a finding of ambiguity is also supported by the text itself given the interplay between the definition of a whistleblower and the subsequent provision prohibiting retaliation, specifically the Third Section. There is a lack of clarity when reading these two provisions together which raises questions as to how the two are compatible and how they should be construed.

With such a finding of ambiguity in Dodd-Frank's anti-retaliation provision, the courts should, and must, analyze canons of statutory interpretation as a second step in the analysis.

\section{B. Step Two: Using Traditional Canons of Statutory Interpretation}

Subsequent to a finding of ambiguity in a statute, courts will look to canons of statutory interpretation to decide how best to decipher the meaning of the statute. There are many canons of statutory interpretation. ${ }^{155}$ The canons are not mandatory rules, but rather are a way to help judges "determine the Legislature's intent as embodied in particular statutory language." 156 The most popular canon, and that which is typically used as a starting point, attempts to view the statute from the legislature's perspective, ${ }^{157}$ and includes looking to the legislature's objectives, the circumstances surrounding the law's adoption, the history of the statute, and

153 But see Verfuerth v. Orion Energy Sys., Inc., No. 14-C-352, 2014 WL 5782514, at *4 (E.D. Wis. 2014) ("[T]he belief that there is some kind of conflict in the statute is based on a flawed understanding of the concept of statutory ambiguity. No term or phrase in the statute is actually ambiguous. Instead, courts perceiving ambiguity appear flummoxed by the simple fact that the protections in the statute extend to activity beyond the activity that qualifies an employee for protection. But, as discussed above, there is nothing 'ambiguous' or conflicting about such a framework at all. Accordingly, the plain language Congress employed should be given full effect.").

154 See id.; Murray v. UBS Sec., LLC, No. 12 CIV. 5914 JMF, 2013 WL 2190084, at *5 (S.D.N.Y. May 21, 2013) ("The existence of these 'competing, plausible interpretations' of the statutory provisions compels the conclusion that 'the statutory text is ambiguous in conveying Congress's intent."').

155 See Yule Kim, Statutory Interpretation: General Principles and Recent Trends, CRS Report for Congress, Congressional Research Service (August 31, 2008), https://www.fas.org/sgp/crs/misc/97589.pdf.

156 Chickasaw Nation v. United States, 534 U.S. 84, 94, 122 S. Ct. 528, 535, 151 L. Ed. 2d 474 (2001).

157 United States v. Great N. Ry., 287 U.S. 144, 154-55 (1932) ("In aid of the process of construction we are at liberty, if the meaning be uncertain, to have recourse to the legislative history of the measure and the statements by those in charge of it during its consideration by the Congress."). 
the legislature's declaration or purpose for the statute. ${ }^{158}$ However, the legislature's intent in creating a statute is not always clear or readily available, and for this reason there are many other canons of statutory interpretation that can be used. ${ }^{159}$

The courts which find for a broad definition of the term whistleblower already provide a sufficient framework for applying canons in reaching their holdings. The following analysis builds on that approach, discussing: (1) legislative history as a canon because it is often the starting point; (2) deference to an administrative agency as a canon under the Chevron doctrine because, while it is thoroughly discussed by the courts, it lends the most support for finding a broad definition; and (3) analyzing definitions as a canon that lends much support but is not focused on by the courts in their analyses.

\section{i. Legislative History}

In the case of Dodd-Frank's whistleblower anti-retaliation provisions, there is little legislative history to guide statutory interpretation. ${ }^{160}$ It makes sense that little legislative history exists in regard to the specific antiretaliation whistleblower provisions, because those provisions are only a small part of a very large piece of legislation which addresses many different subjects. ${ }^{161}$ However, legislative history does exist in regard to Dodd-Frank as a whole, and that history states that Dodd-Frank was enacted as being "a direct and comprehensive response to the financial crisis that nearly crippled the U.S. economy beginning in 2008." 162 The overall goal of the legislation is stated as being "to promote the financial stability of the United States by improving accountability and transparency

158 See generally Morell E. Mullins, Sr., Tools, Not Rules: The Heuristic Nature of Statutory Interpretation, 30 J. LEGIS. 1, 3 (2003).

159 Abbe R. Gluck \& Lisa Schultz Bressman, Statutory Interpretation From the Inside-An Empirical Study of Congressional Drafting, Delegation, and the Canons: Part I, 65 StAN. L. Rev. 901, 940 (2013) ("There are more than 100 substantive canons, and they run the range from transsubstantive policy presumptions (e.g., ambiguous federal statutes will not be construed to intrude on traditional state functions); to subject-specific rules (e.g., ambiguous bankruptcy statutes shall be construed in favor of the debtor); to the dozen or so presumptions that concern delegation of interpretive authority to administrative agencies. These canons are infamously conflicting, overlapping, and manipulable, and have been described as everything from 'judicial lawmaking' to 'democracy protective' to 'constitutional law."”).

160 Egan v. TradingScreen, Inc., No. 10 CIV. 8202 LBS, 2011 WL 1672066, at *4 (S.D.N.Y. May 4, 2011) ("The legislative history of the Act provides little evidence of Congress's purpose. The various committee reports and debates in Congress focus on the bounty provisions of the Act and contain very few substantive discussions of its anti-retaliation provisions.").

161 See Bussing v. COR Clearing, LLC, No. 8:12-CV-238, 2014 WL 2111207 (D. Neb. May 21, 2014) motion to certify appeal granted, No. 8:12-CV-238, 2014 WL 3548278 (D. Neb. July 17, 2014).

162 S. REP. NO. 111-176, at 2 (2010). 
in the financial system, to end 'too big to fail,' to protect the American taxpayer by ending bailouts, to protect consumers from abusive financial services practices, and for other purposes." 163

While this excerpt is helpful in ascertaining the goal of the legislation as a whole, there is little to no legislative history that addresses the exact whistleblower anti-retaliation provisions at issue. ${ }^{164}$ Therefore, legislative history offers little guidance in resolving the issue, creating the need to turn to alternative canons of statutory interpretation. However, the legislative history will offer guidance in a later Section of this Comment when it is discussed relative to public policy. ${ }^{165}$

In the absence of explicit Congressional intent, tracking the language of the bill itself sheds some light on what may have been the intent of Congress. When the bill was introduced, it contained both a bounty program and an anti-retaliation provision. ${ }^{166}$ The bill defined the term whistleblower to be an individual that reports information directly to the SEC. ${ }^{167}$ However, the anti-retaliation provision in the bill did not reference the term whistleblower, instead it referred to "employee, contractor, or agent" as being the individuals who were protected from retaliation. ${ }^{168}$ The original anti-retaliation provisions in the bill only included sections one and two (providing tips to the SEC or assisting in an investigation or proceeding). ${ }^{169}$ Only when the bill passed the Senate was the term "whistleblower" incorporated into the anti-retaliation provision by replacing the words "employee, contractor, or agent."

163 S. REP. NO. 111-176, at 1 (2010).

164 Egan v. TradingScreen, Inc., No. 10 Civ. 8202(LBS), 2011 WL 1672066, at *4 (S.D.N.Y. May 4, 2011) ("The legislative history of the Act provides little evidence of Congress's purpose. The various committee reports and debates in Congress focus on the bounty provisions of the Act and contain very few substantive discussions of its anti-retaliation provisions. Of those few, none touch upon the issue of whether reporting to the SEC is required for whistleblowers to avail themselves of the Act's anti-retaliation provisions.").

165 See supra Part II.

166 Wall Street Reform and Consumer Protection Act of 2009, H.R. 4173, 111th Cong. § 7203 (as introduced in House, Dec. 2, 2009) and (as passed by House, Dec. 11, 2009); see Bussing v. COR Clearing, LLC, 20 F. Supp. 3d 719 (D. Neb. 2014) motion to certify appeal granted, No. 8:12-CV-238, 2014 WL 3548278 (D. Neb. July 17, 2014).

167 Wall Street Reform and Consumer Protection Act of 2009, H.R. 4173, 111 th Cong. $\S 7203$ (as introduced in House, Dec. 2, 2009) and (as passed by House, Dec. 11, 2009); see Bussing, No. 8:12CV-238, 2014 WL 3548278.

168 Wall Street Reform and Consumer Protection Act of 2009, H.R. 4173, 111th Cong. § 7203 (as introduced in House, Dec. 2, 2009) and (as passed by House, Dec. 11, 2009). See Bussing, No. 8:12CV-238, 2014 WL 3548278.

169 Wall Street Reform and Consumer Protection Act of 2009, H.R. 4173, 111th Cong. $§ 7203$ (as introduced in House, Dec. 2, 2009) and (as passed by House, Dec. 11, 2009). See Bussing, No. 8:12CV-238, 2014 WL 3548278.

170 Restoring American Financial Stability Act of 2010, H.R. 4173, 111 th Cong. $§ 922(h)(1)(A)$ (May 20, 2010); see also Bussing, 2014 WL 3548278. 
still only contained the first two provisions of the anti-retaliation protections - there was no Third Section as is seen in the current statute. Therefore, "there was no reason to anticipate that any conflict would arise from the replacement of the phrase 'employee, contractor, or agent' with the term "whistleblower." 171 The Third Section was added later in the process in a draft of the conference committee base text which was used to finalize the act-although no indication was given as to why, other than perhaps as a catch-all provision. ${ }^{172}$ Congress was likely not aware of any inconsistency between the adding of the Third Section and the definition of whistleblower. ${ }^{173}$

By tracking the language of the bill from its inception to the final version, there is clear support for the fact that Congress likely did not intend for the Third Section to be susceptible to the definition of whistleblower. What is more likely is that Congress intended the addition of the Third Section as a catch all provision near the end of finalizing the bill without realizing the incongruity present in this section relevant to the definitional section.

\section{ii. Analyzing Definitions}

Another canon of statutory interpretation is to analyze the definition of the word at issue. One version of this canon is that "[i]f the word or phrase is defined in the statute ... in a 'definitions' section ... or elsewhere in the United States Code, then that definition governs if applicable in the context used." 174 However, in contrast, case law gives further guidance in that "[i]f the context indicates otherwise, i.e., if a mechanical application of a statutory definition throughout a statute would create an 'obvious incongruity' or frustrate an evident statutory purpose for a particular provision, then it is permissible to depart from the definition." 175

Although Dodd-Frank defines a whistleblower as one who reports directly to the SEC, there is an incongruity when this definition is applied to the Third Section of the anti-retaliation provision. ${ }^{176}$ A mechanical application of the term whistleblower to the Third Section applies a restrictive definition to a term that as written, was meant to be broad. As written, the Third Section extends protection to those who have made disclosures required or protected by laws within the SEC's jurisdiction-a

\footnotetext{
171 Bussing, 2014 WL 3548278.

172 Id.

173 Id

174 Kim, supra note 155; see also Colautti v. Franklin, 439 U.S. 379, 392 (1979).

175 Id.; see also Lawson v. Suwannee S.S. Co., 336 U.S. 198, 201 (1949).

176 See generally Bussing v. COR Clearing, LLC, 20 F. Supp. 3d 719, 731 (D. Neb. 2014). motion to certify appeal granted, No. 8:12-CV-238, 2014 WL 3548278 (D. Neb. July 17, 2014).
} 
broad range of disclosures, which can be considered a catch-all provision. To apply the definition of a whistleblower to the Third Section mechanically and to require these disclosures be made to the SEC, unnecessarily restricts this provision, and it no longer becomes such a catch-all to extend protection to those not falling in any other category. The plaintiff in one district court case stated this conundrum as follows: "the definition of the term 'whistleblower' must be too narrow: after all, how could the definition of a whistleblower be limited to people who report to the Commission, when the statute protects against retaliation for disclosures to the whistleblower's employer?"177 Because of this obvious incongruity, it is "permissible to depart from the definition." 178 Therefore, the mechanical definition of a whistleblower should be departed from in the Third Section.

\section{iii. Deference to an Administrative Agency (Chevron Analysis)}

Deference to an administrative agency's rulemaking authority in interpreting a statute is a canon of statutory interpretation that is appropriate in certain situations. The Chevron rule guides the analysis, and allows for deference to an administrative agency's interpretation of a statute if certain requisites are met. The Chevron rule, established in Chevron U.S.A. Inc. v. Natural Resources Defense Council, Inc., ${ }^{179}$ is as follows: "When a court reviews an agency's formal interpretation of a statute that the agency administers, and when the statute has not removed agency discretion by compelling a particular disposition of the matter at issue, courts defer to any reasonable agency interpretation." $"$ Two other cases in 2000 and 2001 narrowed the Chevron rule to create the following two-step application. ${ }^{181}$ Step one is to inquire "whether Congress has directly spoken to the precise question at issue." "182 If the intent of Congress is clear, that is the end of the matter; for the court, as well as the agency, must give effect to the

177 Berman v. Neo@Ogilvy LLC, No. 1:14-CV-523-GHW-SN, 2014 WL 6860583, at *3 (S.D.N.Y. Dec. 5, 2014).

178 Lawson, 336 U.S. at 201 ("Statutory definitions control the meaning of statutory words, of course, in the usual case. But this is an unusual case. If we read the definition ... in a mechanical fashion, we create obvious incongruities in the language, and we destroy one of the major purposes of the ... provision. ... We have concluded that Congress would not have intended such a result.”).

179 Chevron, U.S.A., Inc. v. Natural Res. Def. Council, Inc., 467 U.S. 837, 842-43 (1984).

180 Kim, supra note 155, at 23.

181 Id. ("In two decisions, one in 2000 and one in 2001 the Court clarified and narrowed Chevron's application, ruling that Chevron deference applies only if an agency's interpretation is the product of a formal agency process, such as adjudication or notice-and-comment rulemaking, through which Congress has authorized the agency 'to speak with the force of law.' Other agency interpretations that are made without the protections of a formal and public process are reviewed under pre-Chevron principles set forth in Skidmore v. Swift \& Co.").

182 Id. 
unambiguously expressed intent of Congress. ${ }^{183}$ However, if the statute is silent or ambiguous with respect to the specific issue, the court applies step two--"whether the agency's answer is based on a permissible construction of the statute." 184 Finally, "[i]f the agency interpretation is reasonable, then [a court] must defer to it." "185 This is only the basic premise of the Chevron rule, and while an analysis of statutory interpretation under the Chevron rule is more complicated, it is outside the scope of this article.

The Chevron analysis should be applied to Dodd-Frank's antiretaliation provision because both steps are met. Step one of the analysis is met because the intent of Congress is not clear in regard to the DoddFrank's anti-retaliation provision; this was established above. Step two requires an analysis of the SEC's interpretation on the issue and whether it is a permissible construction of the statute, which analysis follows below.

The SEC, which is the relevant administrative agency, adopted formal rules in 2011 to address the definition of whistleblower and whistleblower retaliation under Dodd-Frank. The SEC formal rules state:

(b) Prohibition against retaliation:

(1) For purposes of the anti-retaliation protections afforded by Section $21 \mathrm{~F}(\mathrm{~h})(1)$ of the Exchange Act (15 U.S.C. 78u-6(h)(1)), you are a whistleblower if:

(i) You possess a reasonable belief that the information you are providing relates to a possible securities law violation (or, where applicable, to a possible violation of the provisions set forth in 18 U.S.C. $1514 \mathrm{~A}(\mathrm{a})$ ) that has occurred, is ongoing, or is about to occur, and;

(ii) You provide that information in a manner described in Section $21 \mathrm{~F}(\mathrm{~h})(1)(\mathrm{A})$ of the Exchange Act (15 U.S.C. 78u-6(h)(1)(A)).

(iii) The anti-retaliation protections apply whether or not you satisfy the requirements, procedures and conditions to qualify for an award. ${ }^{186}$

In its comments, the SEC further expanded on the rule, stating:

The second prong of the Rule $21 \mathrm{~F}-2(\mathrm{~b})(1)$ standard provides that, for purposes of the anti-retaliation protections, an individual must provide the information in a manner described in Section $21 \mathrm{~F}(\mathrm{~h})(1)(\mathrm{A})$. This

\footnotetext{
183 Id

184 See id.

185 Id

186 Whistle Blower Status and Retaliation Protection, 17 C.F.R. $§ 240.21 F-2$ (2011).
} 
change to the rule reflects the fact that the statutory anti-retaliation protections apply to three different categories of whistleblowers, and the third category includes individuals who report to persons or governmental authorities other than the Commission. Specifically, Section $21 \mathrm{~F}(\mathrm{~h})(1)(\mathrm{A})(\mathrm{iii})$ - which incorporate the anti-retaliation protections specified in Section 806 of the Sarbanes-Oxley Act, 18 U.S.C. $1514 \mathrm{~A}(\mathrm{a})(1)(\mathrm{C})$ - provides anti-retaliation protections for employees of public companies, subsidiaries whose financial information is included in the consolidated financial statements of public companies, and nationally recognized statistical rating organizations when these employees report to (i) A Federal regulatory or law enforcement agency, (ii) any member of Congress or committee of Congress, or (iii) a person with supervisory authority over the employee or such other person working for the employer who has authority to investigate, discover, or terminate misconduct. However, the retaliation protections for internal reporting afforded by Section $21 \mathrm{~F}(\mathrm{~h})(1)(\mathrm{A})$ do not broadly apply to employees of entities other than public companies. ${ }^{187}$

The SEC explicitly states that whistleblowers in the Third Category can report to persons other than the SEC itself and still be afforded protection under Dodd-Frank's anti-retaliation provisions. By way of the SEC's interpretation of the statute, whistleblowers making disclosures under the Third Section do not have to report to the SEC in order to file a claim for retaliation under Dodd-Frank. This Comment argues that deference to the administrative agency is appropriate, given the ambiguity present in the statutory text. ${ }^{188}$ Therefore, the Chevron rule in conjunction with the SEC's formal rules on this issue govern relatively clearly that there is no requirement that a whistleblower report $\mathrm{SOX}$ violations to the SEC to bring a retaliation claim under Dodd-Frank.

\section{Non-Traditional Canon of Statutory Interpretation: Public Policy}

While traditional cannons of statutory interpretation lend sufficient support to a finding that whistleblowers do not need to report directly to the SEC when making disclosures under the Third Section of Dodd-Frank's anti-retaliation provision, this Comment argues for use of a non-traditional canon of statutory interpretation, one that lends stronger support to this finding as being in accord with the legislative goals of the statute overall. This Comment suggests that courts look to public policy in guiding its interpretation of the anti-retaliation provisions of Dodd-Frank. Although

18717 C.F.R. $\S \S 240,249$ (emphasis added).

188 An analysis of the applicability of the Chevron rule is outside the scope of this note. 
public policy is not a traditional or frequently used canon of statutory interpretation, it is useful in resolving the present issue.

The following Section discusses two policy considerations in interpreting the anti-retaliation provisions under Dodd-Frank. First, this Section describes when it is appropriate to use public policy in statutory interpretation. Second, this Section refutes the Asadi Court's argument that SOX would be rendered moot if whistleblowers were not required to report to the SEC, and responds with a policy argument showing that the converse also results in rendering SOX moot. Finally, this Section looks to the overall goal of Dodd-Frank to guide the interpretation of the whistleblower provisions to be in accordance with public policy.

\section{i. When to Use Public Policy}

When a court uses public values to guide statutory interpretation, it should analyze the question before it and decide if a public value is at issue. ${ }^{189}$ If a public value is implicated, the court should place less concern on the actual text of the statute and will rather examine the policy underlying the statute. In this case, the court should heavily rely on public value in crafting an interpretation of that statute. ${ }^{190}$ The court may also rely on public policy as a guide for statutory interpretation in the case that conventional methods do not yield results. ${ }^{191}$

The issue of how to interpret Dodd-Frank's anti-retaliation provisions lends itself to using public policy as a guide to statutory interpretation. A public value is at issue in the case of Dodd-Frank's whistleblowers because Dodd-Frank itself was created to address public concerns about the state of the economy after the 2008 recession. The public value implicated is the prevention of economic crises. This goal is clear because it is the underlying impetus that drove both the creation of SOX and Dodd-Frank. ${ }^{192}$ With a clear public value identified, the courts should weigh public value

189 Carlos J. Cuevas, Public Values and the Bankruptcy Code, 12 BANKR. DEV. J. 645, 648 (1996).

190 Id. ("Public values statutory interpretation is a device used by the courts to correct what the judiciary perceives to be an injustice. It is a mode of analysis used for reaching not only the morally right result, but also the result that most furthers public policy."); see also id. at n.18 ("Holy Trinity Church is a historically important decision, standing for the proposition that a court should not blindly adhere to the literal interpretation of a statute. The court should attempt to determine whether the policy underlying the statute would be effectuated by its enforcement in that particular case. Additionally, the court should examine the circumstances surrounding the enactment of a statute to truly determine its legislative purpose.").

191 H. Miles Foy, III, On Judicial Discretion in Statutory Interpretation, 62 ADMIN. L. REV. 291, 299 (2010) ("In other words, if the conventional methods of statutory interpretation are indeterminate, the judge may allow a personal sense of justice, equity, practicality, or sound public policy to determine the outcome.").

192 See supra Part I. 
considerations more heavily in crafting a statutory interpretation rather than strictly analyzing the text of the statute itself.

One scholar offers a solution for effectively integrating traditional statutory interpretation with public policy; the two-step process is as follows. First, "the court uses traditional tools of statutory interpretation, such as text, legislative history, and canons and presumptions of construction, to determine the range of plausible meanings to ambiguous statutory clauses." ${ }^{\text {"193 }}$ In this first step, the court acts as an impartial observer and is trying to gather a range of possible interpretations that may have been intended by Congress. ${ }^{194}$ The second step consists of the court engaging in a policy analysis for each of the possible interpretations collected in step one. ${ }^{195}$ In this second step, "the court's reasoning and analysis centers upon which of the several plausible interpretations is the most public-regarding." 196 According to this scholar, the first step is statutory interpretation while the second step is regarded as statutory construction, whereby the court is shaping statutory law. ${ }^{197}$

Applying this two-step approach to Dodd-Frank's anti-retaliation provisions also leads to a conclusion that the provisions should be interpreted broadly. Under step one, there are two possible interpretations of the statute: (1) a narrow interpretation whereby whistleblowers making disclosures required or protected by SOX must report to the SEC to avail themselves of the anti-retaliation provision; and (2) a broad interpretation whereby whistleblowers making disclosures required or protected by SOX do not have to report to the SEC (an internal report is sufficient) to avail themselves of the anti-retaliation provision. Step two requires a policy analysis of the two possible interpretations. The remainder of this note attempts to do just that - analyze the policy issues at stake between the two possible interpretations of the statute, ultimately finding that policy weighs heavily in favor of a broad reading of the statute.

\section{ii. Public Policy at Issue in Dodd-Frank's Anti-Retaliation Provision}

The Asadi Court made a clear policy argument in favor of a narrow interpretation of the provision at issue; however in making this argument, the Court failed to address the converse of its argument. The policy based contention of the Asadi Court was that if, under Dodd-Frank, whistleblowers reporting disclosures required by SOX are not required to

193 Carlos E. Gonzalez, Reinterpreting Statutory Interpretation, 74 N.C. L. REV. 585, 720 (1996).
194 Id.
195 Id.
196 Id.
197 Id. 
report to the SEC, then SOX will effectively be rendered moot. ${ }^{198}$ According to the Asadi Court, SOX will be rendered moot because if plaintiffs are not required to report to the SEC to avail themselves of DoddFrank's anti-retaliation provisions, then any plaintiff with a retaliation claim will immediately bypass the cause of action in SOX, and go straight to alleging a complaint under Dodd-Frank. The reason for this is that DoddFrank offers much more plaintiff-friendly provisions than SOX does. In making this policy argument, the Asadi Court stated:

$[C]$ onstruing the Dodd-Frank whistleblower-protection provision to extend beyond the statutory definition of "whistleblowers" renders the SOX anti-retaliation provision, for practical purposes, moot. Such a construction has this impact because an individual who makes a disclosure that is protected by the SOX anti-retaliation provision could also bring a Dodd-Frank whistleblower-protection claim on the basis that the disclosure was protected by SOX. It is unlikely, however, that an individual would choose to raise a SOX anti-retaliation claim instead of a Dodd-Frank whistleblower-protection claim. ${ }^{199}$

In rebuttal to this argument, this Comment argues that there is another mootness issue not recognized by the Asadi court. The Asadi court failed to consider that SOX would also be rendered moot if whistleblowers are required to report to the SEC in order to avail themselves of Dodd-Frank's anti-retaliation provision. An employee's decision to blow the whistle is often guided by an incentive structure; ${ }^{200}$ therefore, the Asadi court is right when it states that given the choice, a person would likely choose to bring an anti-retaliation claim under Dodd-Frank rather than SOX. If the statute is interpreted to require whistleblowers, reporting disclosures required by SOX, to report to the SEC to gain advantages under Dodd-Frank, then whistleblowers will do just that. Again, because people are to some extent incentive driven, if people are required to report to the SEC in order to avail

198 Asadi v. GE Energy, 720 F.3d 620, 628 (5th Cir. 2013).

199 Id. at 628-29.

200 See Naseem Faqihi, Choosing Which Rule to Break First: An In-house Attorney Whistleblower's Choices After Discovering a Possible Federal Securities Law Violation, 82 FORDHAM L. REV. 3341, 3348 (2014) (stating in regard to whistleblowers "monetary rewards were shown to be decisive.... offering a large monetary reward or imposing a legal duty to report and granting a large monetary reward provided a very strong incentive for blowing the whistle."); see also Justin Blount \& Spencer Markel, The End of the Internal Compliance World as we Know It, or an Enhancement of the Effectiveness of Securities Law Enforcement? Bounty Hunting Under the Dodd-Frank Act's Whistleblower Provisions, 17 FORDHAM J. CORP. \& FIN. L. 1023, 1052 (2012) ("The size of the bounty is critical, as small monetary awards were not a strong incentive and actually decreased the rate of reporting when there was no moral outrage at the conduct reported."). While money is a contributing factor in a whistleblower's decision to report information, whistleblower incentive structures tend to be much more complicated; see generally id. at 1050-51 (describing in depth different incentive factors). 
themselves of the more beneficial anti-retaliation provisions under DoddFrank, people will most certainly comply with the requirements of DoddFrank to ensure they will be protected in the case of retaliation. ${ }^{201}$ These employees will bypass their companies' internal compliance systems, and report any concerns about securities violations directly to the SEC. ${ }^{202}$ When whistleblowers report directly to the SEC while bypassing internal reporting, the internal compliance systems set up under SOX are destroyed. Companies no longer have the opportunity to remedy violations. ${ }^{203}$ In this instance, SOX is effectively rendered moot, ${ }^{204}$ given the fact that the internal reporting channels painstakingly established by SOX are no longer being utilized and are effectively destroyed. ${ }^{205}$ The policy and impetus

201 See generally Jenny Lee, Corporate Corruption and the New Gold Mine: How the DoddFrank Act Overincentivises Whistleblowing, 77 BROOK. L. REV. 303, 326-27 (“As a result, the DoddFrank Act's unnecessary and excessive bounty program, coupled with its expansive antiretaliation protection, overincentivizes whistleblowing and is likely to lead to the waste of administrative resources.").

202 See generally Thomas S. Markey, III., "Whistleblower" Redefined: Implications of the Recent Interpretative Split on the Dodd-Frank Whistleblower Anti-Retaliation Provision, 33 REV. BANKING \& FIN. L. 441, 449 (2014) (“[T] he Fifth Circuit's interpretation may discourage employees from reporting internally because employees could only gain anti-retaliation protection if they subsequently report to the SEC.”); Shannon Kay Quigley, Whistleblower Tug-of-War: Corporate Attempts to Secure Internal Reporting Procedures in the Face of External Monetary Incentives Provided by the Dodd-Frank Act, 52 SANTA Clara L. Rev. 255, 268-69 (2012) (stating that "employees will 'flee' to the federal government instead of reporting misconduct to the corporation").

203 See generally Rich Steeves, Whistling Down the Wind: The Pitfalls and Possibilities of the Dodd-Frank Whistleblowing Program, INSIDE COUNSEL (Jan. 27, 2014), http://www.insidecounsel.com/ 2014/01/27/whistling-down-the-wind-the-pitfalls-and-possibili ("[C]ompanies would prefer to have no problems that would warrant whistleblowing in the first place. But, if workers do have an inkling that something untoward is happening, they have two primary options: reporting internally or externally. Due to the considerable risk of prosecution, sanctions and damage to reputation associated with whistleblowers who report to the SEC, businesses would certainly prefer if matters are handled in house.").

204 See generally Quigley, supra note 202 at 268-69 ("The Dodd-Frank Act adversely encourages whistleblowers to report to the government, instead of the corporation, by increasing monetary incentives and strengthening the protections provided to employees. This decreases the effectiveness of compliance programs by reducing the number of employees willing to utilize internal reporting mechanisms.... [M]any ... companies, criticize the Dodd-Frank Act for damaging their internal compliance programs. Prior to the enactment of the SEC's rules under the Dodd-Frank Act, SEC Commissioner Troy Paredes admitted that the proposed rules 'might not do enough to preserve the important role that corporate compliance programs serve. It would be unfortunate if, as a result of the Dodd-Frank whistleblower program, effective corporate compliance programs were thwarted."'); $i d$. at 271 ("As the employee weighs the benefits and disadvantages of reporting externally, an employer faced with a potential violation may report to the government prematurely in an attempt to gain sentencing benefits. If the corporation has not completed a thorough investigation, the employer is inviting the government to examine the company even when a securities law violation did not occur.").

205 See generally Deborah A. DeMott, The Crucial but (Potentially) Precarious Position of the Chief Compliance Officer, 8 BRoOK. J. CORP. FIN. \& COM. L. 56, 73 (2013) ("[S]ome commentators feared that Dodd-Frank's whistleblower provisions would 'undermine the effectiveness of ... internal compliance programs' because Dodd-Frank created incentives in the form of a monetary reward program (not at issue in Asadi) to report directly to the SEC."); William McLucas, Laura Wertheimer \& 
behind SOX is destroyed when the internal compliance systems it created are destroyed.

It seems like either way, whether whistleblowers must or need not report to the SEC to avail themselves of Dodd-Frank, SOX is left moot in some way. So, the question that results is, which of the two evils should courts choose? Which construction is in the best interest of public policy? Is it more important to preserve the legacy of SOX through internal compliance structures, effectively preserving the overall goal of both statutes, which is to prevent financial crisis, and thus allow Dodd-Frank to operate in conjunction with SOX? Or is it more important to essentially bifurcate the two statutes, demanding that the two causes of action remain wholly distinct, thereby forcing plaintiffs to comply with strict requirements to avail themselves of either provision simply in order to preserve a cause of action under SOX, by procedurally forcing plaintiffs to choose one statute over the other?

This note argues in favor of the former contention - until Congress amends the statute to give a more clear understanding of its true intentions, courts should aim to preserve the overall policy goals of both Dodd-Frank and SOX. This can be done by interpreting Dodd-Frank to allow for whistleblowers who report internally to file a retaliation claim action under Dodd-Frank. Thereby, courts can preserve the legacy of SOX by ensuring that internal compliance systems remain intact while at the same time promoting the policy goals of each statute by encouraging whistleblowers to report securities fraud by providing them with the much more plaintiff friendly provisions under Dodd-Frank. The following sections discuss why it is in the best interest of public policy to interpret Dodd-Frank in a way that also preserves the policy goals of SOX — both of which are to prevent future economic crises in this country. This course of action accomplishes this goal in two ways: first, it supports whistleblowers, who are vital ingredients in exposing violations and fraud, and second, it preserves internal compliance systems set up by SOX, essential to remedying violations internally.

First, the support of whistleblowers is a public value at issue in this

Arian June, Don't Tread on Whistleblowers: Mitigating and Managing Retaliation Risks, 46 SEC. REG. \& L. REP. (BNA) 77, at *10-11 (Jan. 13, 2014) ("Director McKessy recently noted the 'irony' that 'many of the companies' which had urged the SEC to impose mandatory internal reporting requirement in its implanting rules before an individual could qualify for a SEC whistleblower bounty were not arguing that individuals who reported internally would not be entitled to Dodd-Frank protection from retaliation. He speculated that, "if word gets out that reporting internally means you will be unprotected, that may drive people to report to [the SEC]' and bypass internal reporting channels to ensure that they are protected against retaliatory conduct."); Markey, supra note 202, at $450 \mathrm{n} .64$ ("arguing that the Fifth Circuit's interpretation will 'frustrate' the SEC's 'careful and laborious efforts' to promote compliance with securities laws without undermining companies' internal reporting structures"). 
case-one which should be protected given the importance of whistleblowers in exposing corporate violations. Whistleblowers can be an important part of preventing securities fraud because, as corporate employees, they are often the ones who bring forward claims of corporate wrongdoing. ${ }^{206}$ Congress crafted the whistleblower regulations of SOX with the importance of whistleblowers in fraud detection in mind. ${ }^{207}$ The benefit of employees acting as whistleblowers is that employees often have access to information that others lack. ${ }^{208}$ Employees have access to their companies' current information, and are therefore typically the first people who realize that something is wrong. ${ }^{209}$ A study of the Association of Certified Fraud Examiners found that forty-six percent of all frauds were uncovered by whistleblowers. ${ }^{210}$ Protecting whistleblowers does two things: it encourages legal compliance, which benefits the public, and can lighten the burden of government regulators on ensuring that companies are in compliance. ${ }^{211}$ Protection of whistleblowers is within the policy goals of both Dodd-Frank and SOX because at each statutes' core is the desire to prevent economic crises. A broad interpretation of the statutes does just this: it affords whistleblowers greater options and does not procedurally force them into complying with a reporting scheme or structure. Perhaps whistleblowers are more comfortable coming forward with information internally than to the SEC. It is possible that a mandate to report to the SEC may discourage some whistleblowers, thereby creating a hindrance to the overall goal of the statute.

Second, another public value at issue is the preservation of SOX's internal compliance systems which address potential securities violations within a company. ${ }^{212}$ Potential violations of fraud are best dealt with

206 See Rachel Beller, Whistleblower Protection Legislation of the East and West: Can It Really Reduce Corporate Fraud and Improve Corporate Governance? A Study of the Successes and Failures of Whistleblower Protection Legislation in the U.S. and China, 7 N.Y.U. J. L. \& BUS. 873, 902 (2011).

207 See generally Jisoo Kim, Confessions of $A$ Whistleblower: The Need to Reform the Whistleblower Provision of the Sarbanes-Oxley Act, 43 J. MARSHALL L. REV. 241, 249-50 (2009) ("Moreover, in a recent study measuring the effectiveness of various methods of detecting corporate fraud, internal employees - in other words, whistleblowers - turned out to be the most effective monitors in detecting fraud.").

208 See id.

209 See Whistleblower Protection: Encouraging Reporting, OECD (July 2012), http:// www.oecd.org/cleangovbiz/toolkit/50042935.pdf.

210 See Changing Corporate Culture, NAT'L WHISTLEBLOWERS CTR. (last visited Apr. 10, 2014), http://www.whistleblowers.org/index.php?option=com_advancedtags\&view=tag\&id=80 ("In the 2008 Report to the Nation on Occupational Fraud and Abuse, the ACFE examined 959 cases of fraud related to American corporations.").

211 See Naseem Faqihi, Choosing Which Rule to Break First: An In-house Attorney Whistleblower's Choices After Discovering A Possible Federal Securities Law Violation, 82 FORDHAM L. REV. 3341, 3355 (2014).

212 See generally Alison B. Miller, Navigating the Disclosure Dilemma: Corporate Illegality and 
internally as opposed to externally as it gives the company an opportunity to fix what may be wrong. ${ }^{213}$ Affording companies the opportunity to investigate claims of potential securities violations allows them to be remedied before they are reported to the federal government. ${ }^{214}$ The benefits of internal reporting by whistleblowers include the prompt investigation of concerns, the opportunity to correct wrongful conduct, and to allow for a correction of misunderstandings. ${ }^{215}$ Allowing a narrow interpretation of the statutes effectively eliminates the internal compliance systems, but a broad interpretation preserves such systems. Finding for the broad interpretation is in the best policy interest.

\section{CONCLUSION}

The situation is ripe for a circuit split. If a circuit split does ensue in the near future, and if this issue eventually reaches the level of the United States Supreme Court, the Court should interpret the anti-retaliation provisions under Dodd-Frank to find that a whistleblower need not report directly to the SEC when making disclosures required by SOX in order to

the Federal Securities Laws, 102 GEO. L.J. 1647, 1649-50 (2014) ("The Sarbanes-Oxley Act of 2002 (SOX) strengthened internal compliance requirements, establishing the corporate audit committee as a gatekeeper responsible for policing accounting and financial reporting fraud. Under SOX, audit committees must be authorized to receive complaints and retain outside, independent counsel in the event an investigation is warranted. DOJ and SEC memoranda have also emphasized that a company's willingness to cooperate with regulators - such as by taking remedial actions or voluntarily disclosing wrongdoing - is a crucial factor that influences agency enforcement decisions.").

213 See Corporate Law - Securities Regulation - Congress Expands Incentives for Whistleblowers to Report Suspected Violations to the Sec. - Dodd-Frank Act, Pub. L. No. 111-203, S 922, 124 Stat. 1376, $1841-49$ (2010) (to Be Codified, 124 HARV. L. REv. 1829, 1834-35 (2011) (““'[i]f . . . the primary goal of whistleblowing is reduction of wrongdoing rather than prosecution of wrongdoers, and the speed with which problems are addressed is significant, then internal whistleblowing should be preferred' to external whistleblowing. ... Because a 'culture of compliance and integrity' is vital to the maintenance of effective internal compliance programs, and the 'sine qua non requirement for these programs to work ... is the expectation that employees will report misconduct internally,' this incentive to report externally could unravel the years of effort that have been put into maintaining healthy internal compliance systems.").

214 See Nicole H. Sprinzen, Asadi v. GE Energy (Usa) L.L.C.: A Case Study of the Limits of Dodd-Frank Anti-Retaliation Protections and the Impact on Corporate Compliance Objectives, 51 AM. CRIM. L. REV. 151, 152 (2014) ("Companies want their employees to first report alleged legal violations internally - not externally - so that they can investigate the allegation, decide whether there is a violation, and determine whether they can defend against the allegation, identify any wrongdoers, and remediate the situation."); see also Kevin Rubinstein, Internal Whistleblowing and Sarbanes-Oxley Section 806: Balancing the Interests of Employee and Employer, 52 N.Y.L. SCH. L. REV. 637, 638-39 (2008) ("In many cases, the most effective method of correcting corporate misconduct is by reporting violations internally to supervisors or senior managers who may be unaware of problems within the company."); Terry Morehead Dworkin \& Elletta Sangrey Callahan, Internal Whistleblowing: Protecting the Interests of the Employee, the Organization, and Society, 29 AM. BUS. L.J. 267, 300 (1991).

215 See Terry Morehead Dworkin, Sox and Whistleblowing, 105 Mich. L. REV. 1757, 1760 (2007). 
later bring a retaliation claim. The Court should find that the Third Section, under Dodd-Frank's anti-retaliation provision, is an exception to the general definition of a whistleblower.

Not only do the traditional canons of statutory interpretation, when applied to the anti-retaliation provisions of Dodd-Frank, lead to this conclusion, but potentially more importantly, it is in the best interest of public policy to interpret the statutes this way. After all, the overall goals of SOX and Dodd-Frank is to prevent financial economic crises. This goal is best served by maintaining internal compliance systems and providing whistleblowers with adequate protection.

There may be concerns that allowing courts to engage in such a flexible form of statutory construction will allow the courts to implement their own policies, rather than those of Congress. ${ }^{216}$ However, of equal concern is that engaging in a strictly textualist approach to statutory interpretation will defeat the original Congressional intent and purpose behind a particular statute. ${ }^{217}$ In reality, there is little concern over the court shaping statutory law because it does not have the same incentive as Congress for molding statutes to conform with "interest-group-serving deals aimed at serving narrow constituencies carrying disproportionate voices at the expense of broader public concerns." ${ }^{218}$ Further, the judicial process, unlike the legislative one, is based on reasoning and analysis instead of politics and bargaining. ${ }^{219}$ Other benefits of allowing courts to engage in such an analysis are that it "allows [for] the incorporation of information the enacting Congress could not have accessed, such as how the statute functions in practice, changes in the legal landscape, and changes in underlying social values."220 This theory can be in accord with the separation of powers. ${ }^{221}$ Interpreting a statute to be in accord with public

216 Maura A. Flood, "Kennewick Man" or "Ancient One"? - A Matter of Interpretation, 63 MONT. L. REV. 39, 64 (2002).

217 Id.

218 Carlos E. Gonzalez, Reinterpreting Statutory Interpretation, 74 N.C. L. REV. 585, 720 (1996).

$219 I d$. at 722 ("Under the two-step interpretive process, political bargaining determines the parameters of statutory policy, and in cases of ambiguity the reasoned analysis of the judicial process works along public-regarding lines.”).

$220 \quad I d$.

221 Id. at 722-23 ("Apart from and much more important than these prudential concerns, the twostep approach to statutory interpretation, unlike statutory interpretation theories rooted in the honest agent conception, is fully compatible with the popular sovereignty and separation of powers theory of the federal Constitution. By affording courts an institutional role in shaping statutory law along publicregarding lines, the federal courts are transformed from agents of Congress into agents of the people. Yet the first step of the interpretive process, which constrains the range of the judicial policy discretion in the second step, insures that the institutional role of Congress is not emasculated or rendered superfluous. The two-step process, in short, affords both the first and third branches separate but overlapping roles in the making of statutory law. When authoring a statute Congress checks the courts by setting the parameters of judicial discretion; the courts check Congress by shaping ambiguous 
policy is typically not the role of the court. However, as discussed above, public values and public policy can guide statutory interpretation to a certain extent. If Congress finds that the court interprets the statute in an inappropriate way or in a way that is divergent from its original intentions, Congress can certainly amend the statute to reflect its true goals. However, equally as likely is the fact that Congress may not amend the statute, thereby agreeing with the court's interpretation as being in the best interest of public policy.

In future cases, this Comment suggests that courts use a broad interpretation of the Third Section, or 15 U.S.C. $\S 76 \mathrm{u}-6(\mathrm{~h})(1)(\mathrm{A})(\mathrm{iii})$, finding it to be an exception to the general rule that whistleblowers must report to the SEC in order to bring a retaliation claim under Dodd-Frank. This construction will allow whistleblowers who report claims covered by SOX, and who suffer retaliation because of it, to file claims for retaliation under Dodd-Frank without having to first report those claims directly to the SEC. Whistleblowers who find it best to report concerns internally, and who later suffer retaliation based on their internal reports, will still be afforded retaliation protection under Dodd-Frank.

By allowing whistleblowers who report internally to bring retaliation claims under Dodd-Frank, the courts will allow SOX and Dodd-Frank to work in conjunction with one another to better serve the public policy goals of both, which is to prevent future economic crises. As noted, whistleblowers can be an important part of early detection of securities fraud, and by interpreting Dodd-Frank in the way suggested, the internal compliance systems of SOX are preserved, which allows companies the chance to remedy violations internally before they become a larger problem.

\footnotetext{
statutory law within those parameters. Finally, Congress may again check the courts by revising or clarifying statutes. Each branch plays a distinctly different institutional role but also operates as a peer or coequal player in the statutory law-creating game. The two-step approach to statutory interpretation represents a moderate option between the honest agent conception at one extreme and the radical revisionary approach at the other. While the honest agent conception renders the federal courts subordinate agents of Congress, and the radical revisionary interpretive approach renders the acts of Congress impotent, the two-step approach to statutory interpretation allows both Congress and the federal courts to act as agents of the people, with neither subordinate to the other.").
} 